ROLE OF IONS IN ACTIVATION OF HUMAN LYMPHOCYTES

A THESIS PRESENTED

TO

THE FACULTY OF GRADUATE STUDIES

UNIVERSITY OF MANITOBA

IN PARTIAL FULFILMENT OF THE REQUIREMENTS

FOR THE DEGREE OF MASTER OF SCIENCE

BY

JANE LYALL PEARSON

DEPARTMENT OF ANATOMY

HUMAN GENETICS

OCTOBER 1981 


\section{ROLE OF IONS IN ACTIVATION OF HUMAN LYMPHOCYTES}

BY

JANE LYALL PERSON

A thesis submitted to the Faculty of Graduate Studies of the University of Manitoba in partial fulfilment of the requirements of the degree of

MASTER OF SCIENCE

(c) 1981

Permission has been granted to the LIBRARY OF THE UNIVERSITY OF MANITOBA to lend or sell copies of this thesis, to the NATIONAL LIBRARY OF CANADA to microfilm this thesis and to lend or sell copies of the film, and UNIVERSITY MICROFILMS to publish an abstract of this thesis.

The author reserves other publication rights, and neither the thesis nor extensive extracts from it may be printed or otherwise reproduced without the author's written permission. 
INDEX

$\begin{array}{lc}\text { ABSTRACT } & 2 \\ \text { ACKNOWLEDGEMENTS } & 3 \\ \text { INDEX OF FIGURES } & 4 \\ \text { INDEX OF TABLES } & 6 \\ \text { INTRODUCTION } & 7 \\ \text { LITERATURE REVIEW } & 9 \\ \text { MATERIALS AND METHODS } & 38 \\ \text { RESULTS } & 46 \\ \text { DISCUSSION } & 76 \\ \text { REFERENCES } & 96\end{array}$


ABSTRACT

The role of extracellular ions in activation of PHA stimulated lymphocytes was examined. Cells were cultured in media containing varying levels of $\mathrm{K}^{+}, \mathrm{Mg}^{++}$, and $\mathrm{Ca}^{++}$. Lymphocyte transformation was monitored by measuring nuclear diameter, and by evaluating the area of nucleolus which reacted with silver nitrate.

Decreasing extracellular $\mathrm{K}^{+}$from normal levels $(5.0 \mathrm{mM})$ to $14 \%$ of normal ( $0.7 \mathrm{mM})$, and decreasing extracellular $\mathrm{Mg}^{++}$from normal levels $(1.0 \mathrm{mM})$ to $14 \%$ of normal $(0.14 \mathrm{mM})$, did not affect nuclear diameter or silver nitrate reactivity of PHA stimulated 1ymphocytes, nor did it affect the number of AgNoRs in metaphase cells.

Chelation of extracellular Ca+H with EGTA, during the first 24 hours post stimulation, completely inhibited the increases in silver reactivity, nuclear diameter, and cell division associated with PHA stimulation. Addition of EGTA, 48 hours post PHA, did not inhibit Iymphocyte stimulation. Inhibitory effects of EGTA were completely reversed if $\mathrm{CaCl}_{2}$ was added to the medium within 24 hours of PHA stimulation. By 48 hours, the effects were irreversible. Therefore, $\mathrm{Ca}^{+}$is essential for activation of genes coding for proliferation of 1ymphocytes in vitro.

Increasing extracellular $\mathrm{Ca}^{++}$(to $7.8 \mathrm{mM}$ ) and/or calmodulin, did not significantly activate the proliferative genes of lymphocytes cultured without PHA. 
ACKNOWLEDGEMENTS

I wish to express sincere appreciation to all who have assisted in the completion of this research. It has been my privilege to have had the invaluable guidance of Dr. M. Ray: His interest and availability were greatly appreciated, especially in the preparation of this manuscript.

Special thanks and appreciation are extended to Dr. H.E. Welch, Department of Zoology, whose interest and encouragement have been instrumental in my academic and personal development.

Thanks to Alice Vust for sharing her expertise in tissue culturing and Karen James for her assistance in typing this manuscript.

I wish to thank Dr. M.S. Nijjar, Department of Pathology, University of Manitoba for his gift of calmodulin.

I gratefully acknowledge the assistance of the Department of Photography, Health Sciences Centre. In particular, the artistic skill and patience of Marvin Dlughosh was greatly appreciated.

Thanks to my friends who have tolerated me during the ups and downs of this study. Special mention must be made of Susan Pearson and John Drabble for their editorial advice, and of my fellow students Dennis Curle and Allan McNally.

I am greatly indebted to the MRC Graduate Assistantship and the Children's Hospital of Winnipeg Research Foundation for financing this research project. 
INDEX OF FIGURES

PAGE NO.

1. Arrangement of rRNA gene sequences.

2. Schematic presentation of nucleolus.

3. Evaluation of Iymphocyte silver reactivity

(unstimulated cells).

4. Evaluation of lymphocyte silver reactivity (PHA stimulated cells).

5. Histograms showing silver reactivity and nuclear diameter of lymphocytes at various times after culturing with and without PHA.

6. Graph of relationship of silver reactivity to nuclear diameter. diameter of lymphocytes cultured in $\mathrm{K}^{+}-$and $\mathrm{Mg}^{++}$ reduced media.

8. Histograms showing nuclear diameter and silver reactivity of lymphocytes treated for 24 hours with various concentrations of EGTA.

9. Lymphocytes with silver reactive areas dissociated from the nucleolus of interphase cells.

from the nucleolus of interphase cells and the NORs of metaphase cells.

11. Histograms showing silver reactivity and nuclear diameter of lymphocytes treated with EGTA for various periods of time.

12. Histograms showing silver reactivity of 1ymphocytes at various times after culturing in EGTA treated medium and after adding $\mathrm{CaCl}_{2}$ at various intervals to EGTA. 
PAGE NO.

13. Histograms showing nuclear diameter of lymphocytes at various times after culturing in EGTA treated medium and after adding $\mathrm{CaCl}_{2}$ at various intervals to EGTA treated cells.

14. Histograms showing lymphocyte silver reactivity and nuclear diameter with and without adding $\mathrm{CaCl}_{2}$ to cultures.

15. Histograms showing lymphocyte silver reactivity and nuclear diameter with and without adding calmodulin to cultures.

16. Histograms showing lymphocyte silver reactivity after culturing cells for various periods of time with and without calmodulin.

17. Histograms showing 1ymphocyte nucleus diameter after culturing cells for various periods of time with and without calmodulin.

18. Model of possible role of $\mathrm{Ca}^{+t}$ in PHA stimulation of lymphocytes. 65 
TABLE

PAGE NO.

1. Mean number of silver reactive metaphase chromosomes (AgNORs) after various treatments. 


\section{INTRODUCTION}

\section{REGULATION OF GENE ACTIVITY}

Only a fraction (2-15\%) of the genetic potential of a cell is expressed (Grouse et al., 1972). The fraction expressed fluctuates in response to physiological signals. Thus cells having the same genetic potential may be differentially activated to fulfill different, specialized functions. The mechanics of regulating gene activity is not only of fundamental importance to understanding how normal cells function, but also is paramount to understanding the autonomous proliferation of neoplastic cells, which are not controlled by normal cell regulatory mechanisms.

Little is known of the mechanisms involved in regulation of eukaryote gene expression, though various models have been proposed. Some are patterned after bacterial models, postulating highly specific repressor, derepressor and inducer molecules that interact with specific genes. Others involve the binding of hormone complexes either to chromatin acceptor sites or to cell membrane receptors. These stimulate intracellular activation or inactivation of a biochemical reaction affecting gene expression. The regulation of the highly reiterative rDNA is likely to be different from that of unique sequence DNA. 
II. APPROACH TO STUDY

Human lymphocytes were stimulated by phytohemagglutinin (PHA) to reenter the cell cycle. Reentry involves turning on of those repressed genes which code for the proliferogenic components. Stimulation of Iymphocyte activity is morphologically characterized by an increase in nuclear and nucleolar size, and by an increase in the ability of the nucleolus to reduce colourless silver nitrate $\left(\mathrm{AgNO}_{3}\right)$ to black metalic silver (Schwarzacher et al., 1978; Arrighi et al., 1980). These morphological changes are directly related to stimulation of rRNA genes.

The role of ions in regulation of 1ymphocyte activation was investigated by altering the extracellular concentrations of $\mathrm{K}^{+}, \mathrm{Mg}^{++}$ and $\mathrm{Ca}^{++}$. Activity of rRNA genes was monitored by measuring the diameter of the nucleus and the silver reactivity of the nucleolus.

Examination of the model system utilized, and of theories of regulation of rDNA activity will aid in understanding the role of ions in regulating rDNA activity. 


\section{LITERATURE REVIEW}

\section{ACTIVATION OF LYMPHOCYTES WITH PHYTOHEMAGGLUTININ (PHA)}

The small peripheral blood lymphocyte was considered to be a fully differentiated cell, incapable of division. Nowel1 (1960) found that PHA, a mucoprotein extract of the bean plant, Phaseolus vulgaris, caused a high percentage of Iymphocytes to undergo mitosis. It is a potent mitogen, stimulating 80 to $90 \%$ of small 1ymphocytes to reenter the cell cycle (Douglas, 1972)。Cultured Iymphocytes remain in a non-growing state unless exposed to a mitogen which induces cells to transform by enlarging, producing $\mathrm{RNA}_{\text {, replicating }}$ DNA and undergoing mitosis.

Transformation induced by PHA is initiated by an interaction with membrane receptors (Kornfeld and Kornfeld, 1970). Soon after, membrane-bound adenylate cyclase rapidly increases in activity resulting in an increase in the two primary intracellular regulators, cyclic adenosine $3^{\prime}, 5^{\prime}$-monophosphate (cAMP) (Smith et al。, 1971), and $\mathrm{Ca}^{++}$(Whitney, 1972).

After PHA treatment a sequence of morphological changes occurs in human lymphocytes. Nucleus and total cell size, cytoplasmic basophilia and number of vacuoles progressively increase. Mitotic cells are first observed at about 40 hours after the addition of the mitogen, and the number observed peaks at about 72 hours (Ling, 1968). 
After as little as 4 hours of exposure to PHA, the nucleolus may begin to enlarge (Douglas, 1972) and the silver reactivity of the nucleolus increases (Arrighi et al., 1980), probably due to the stimulation of nucleolar rRNA synthesis. At about 48-60 hours there are ribosomal aggregates in the cytoplasm and increased amounts of rough endoplasmic reticulum, golgi apparatus and lysosomes. Mitochondria often are swollen and show loss of cristae (Douglas, 1972).

PHA stimulates protein synthesis, initially by increasing the efficiency of pre-existing ribosomes and by preventing wastage, and later by utilizing newly synthesized ribosomes. Prior to PHA, about $30 \%$ of ribosomes are engaged in protein synthesis. Soon afterwards about $70 \%$ are engaged (Cooper, 1972). Approximately half of rRNA of unstimulated lymphocytes is degraded. This wastage is virtually eliminated after PHA treatment (Cooper and Gibson, 1971). Waste control may be a mechanism for cells to quickly shift from the resting state to rapid growth upon the appropriate stimulus (Cooper, 1972). Chronic 1ymphatic leukemia cells are characterized by their inability to reverse the wastage of ribosomes upon stimulation (Rubin, 1971). rRNA production increases as in normal cells but the onset of blastogenesis is delayed.

The increase in efficiency of pre-existing ribosomes and control of wastage is not adequate for normal cell growth and division. Blockage 
of rRNA synthesis prohibits DNA synthesis and thus cell proliferation (Kay et al., 1969). In a PHA stimulated nucleolus there is a drastic increase in polymerase A activity (Cooke and Brown, 1973) accompanied by a 10-to 50-fold increase in newly synthesized rRNA (Cooper, 1972) which peaks at around 18 hours (Purtell and Anthony, 1975). PHA does not stimulate all lymphocytes. Approximately 10 to $20 \%$ of Iymphocytes are not transformed. Purtel1 and Anthony (1975) found two rRNA processing pathways in guinea pig lymphocytes, only one of which was stimulated by PHA. This may be explained either by the existence of two major subpopulations of cells, only one of which is preferentially stimulated by $\mathrm{PHA}$, or by all lymphocytes having the potential to use both pathways.

It is not known how PHA activates the genetic components necessary for proliferation. It is known that rRNA synthesis is essential for DNA synthesis and thus for cell proliferation. Regulation of rRNA synthesis may be exercised during transcription, maturation or degradation. 
II. RIBOSOMAL RNA (rRNA) PRODUCTION AND PROCESSING

\section{A. General}

At least $80 \%$ of total cellular RNA is rRNA (Darnel1, 1968). Genes coding for $18 \mathrm{~S}$ and $28 \mathrm{~S}$ rRNA are located in the nucleolar organizing regions (NORs) of human acrocentric chromosomes (Henderson et ale, 1972). During interphase rRNA is transcribed in the nucleolus and modified to produce the precursor molecules of ribosomes. In the cytoplasm, ribosomes translate messenger RNA (mRNA) to produce protein. The activity of the ribosomal cistrons might be controlled at any stage from transcription into RNA to the translation of active proteins.

\section{B. Ribosomal DNA}

It has been demonstrated by in situ hybridization that the chromosomal location of genes coding for $18 \mathrm{~S}$ and $28 \mathrm{~S}$ rRNA are NORs (Henderson et al., 1972). The NoRs of humans are situated at the secondary constrictions of the short arms of the five pairs of acrocentric chromosomes (13, 14, 15, 21 and 22) (Ohno et al., 1961). DNA clusters coding for $5 \mathrm{~S}$ rRNA are scattered outside the NOR, primarily on the larger chromosomes. 
genome, encode for human $18 \mathrm{~S}$ and $28 \mathrm{~S}$ rRNA (Jeanteur and Attardi, 1969). Some 2000 genes per haploid genome encode for $5 S$ rRNA (Hatlen and Attardi, 1971). This high degree of repetition allows for rapid production of ribosomes. The capacity for ribosome production in hepatocytes was estimated to be 15- to 50-fold greater than the consumption of ribosomes (Hadjiolov and Nikolaev, 1976). If rRNA is maximally loaded with RNA polymerase, as found by Spring et al. (1974), the control of rRNA processing is critical. The rDNA is organized into transcriptional units, separated from adjacent regions by non-transcribed spacers (Fig. I)。 The transcriptional units are highly reiterative, containing up to several hundred rDNA copies in a cluster. Units from different species vary in length, primarily due to the presence of transcribed spacers. Spacers are segments of gene elements which do not relate to any cytoplasmic products. The evolutionary trend is for transcribed units to increase in size, primarily due to an increase in length of the transcribed spacer units. The lengths of the $18 \mathrm{~S}$ and $28 \mathrm{~S}$ RNA sequences has been highly conserved during evolution, indicating it must be under stronger genetic pressure than the rest of the transcribed unit.

Sequences of nucleotides in rDNA are not random. Up to $78 \%$ of the base pairs are guanine and cytosine (Hadjiolov and Nikolaev, 1976). Strong conservation of $18 \mathrm{~S}$ and $28 \mathrm{~S}$ rDNA nucleotide sequences occurs throughout a wide range of eukaryotes (Evans, 1977). 


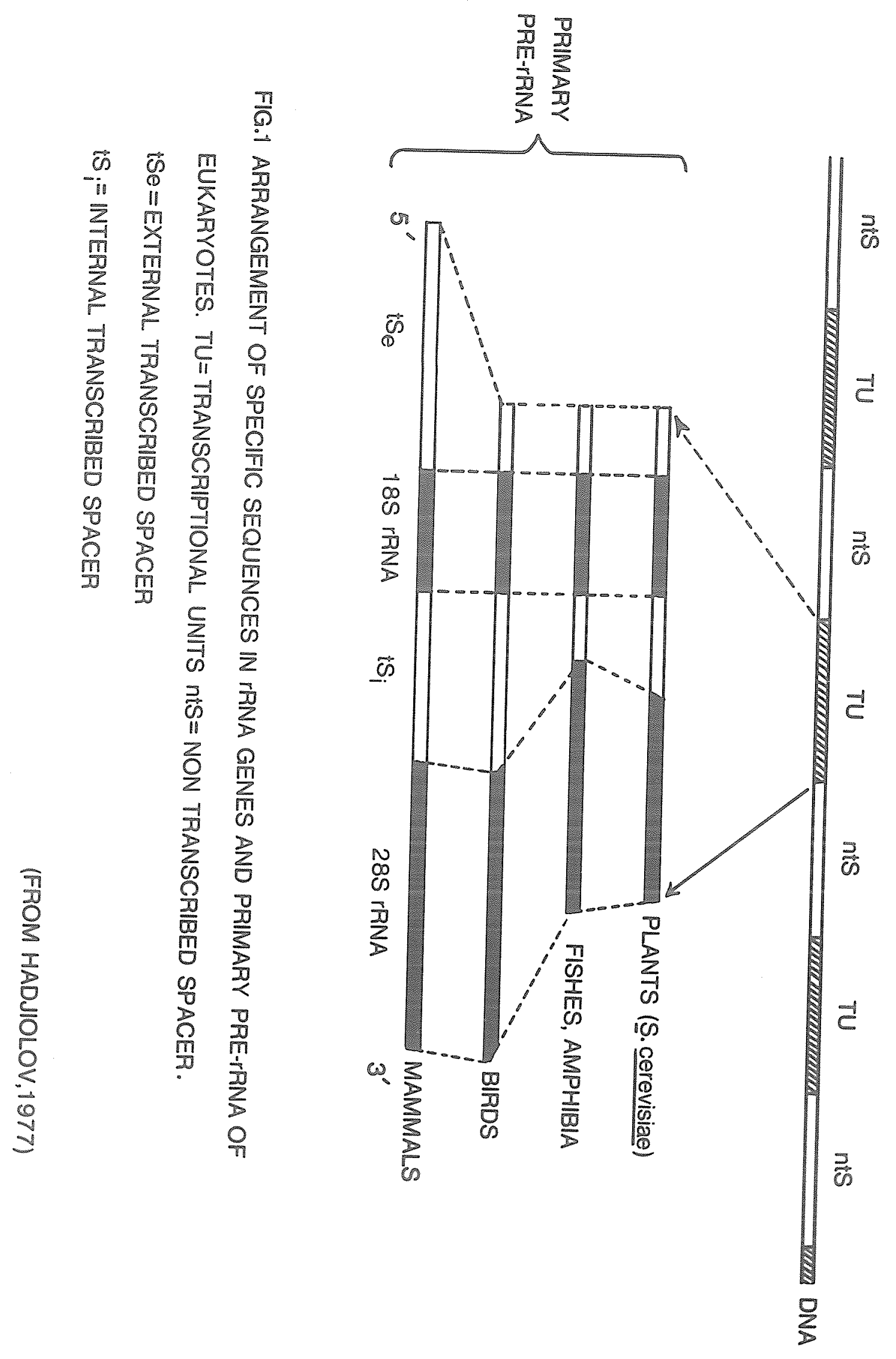


Spacer sequences differ widely, even between closely related species. In Xenopus laevis and Xenopus mulleri hybrid cells, rRNA of $x_{0}$ laevis is preferentially transcribed (Honjo and Reeder, 1973). Their $18 \mathrm{~S}$ and $28 \mathrm{~S}$ sequences are indistinguishable by molecular hybridization. Spacer units are of the same length, but their G-C content has diverged enough to allow separation with cesium chloride (Miller and Hamkalo, 1972), and to be distinguished by molecular hybridization (Honjo and Reeder, 1973). Spacer sequences may play an important role in regulation of transcription or processing. Silver nitrate is histochemically reduced to form black spheres at the NORs (AgNORs). All NORs do not react. In humans a characteristic number of AgNoRs occur, with a mode of 8 per cell (Ray and Pearson, 1979). As RNase and DNase do not eliminate silver reduction, while pretreatment with trypsin or pronase does, it has been concluded that an acid protein is responsible for the silver nitrate reaction (Schwarzacher et al., 1978). Studies of human-mouse somatic cell hybrids showed that the silver reaction detects sites of rRNA activity, rather than the amount of rRNA or DNA (Miller et al., $1976 \mathrm{a} \& \mathrm{~b}$ ). 
C. Nucleolus

1. Introduction

The nucleolus is the established site of pre-rRNA synthesis and maturation. This involvement in the production of the protein synthesizing machinery of the cell gives the nucleolus a prominent position in cell metabolism.

Nucleolar structure and function is dynamic. It changes with cell cycle variations (Grant, 1972; Grummt et al., 1977), with diumal rhythms (Glasser and Spelsberg, 1972), and with cell differentiation (Grummt, 1978). The size and activity levels of the nucleolus increase after stimulation with mitogens such as PHA (Schwarzacher et al., 1978), with hormones or serum, and after fusion of cells to form hybrid heterokaryons (Ringertz et a1., 1971). A prominent nucleolus characterizes cells engaged in intensive protein synthesis.

Nucleolar hypertrophy is striking in most malignant and virus infected cells (Bernhard, 1966). The increase in size is usually accompanied by structural variations. Inhibition of rRNA synthesis with low doses of Actinomycin D (AMD), reduces the size of nucleolus and has a cytostatic effect on a variety of tumors. Control of nucleolar activity is central to a cell's ability to respond normally to physiological stimuli. 


\section{Structure and function}

, The nucleolus was discovered by Fontana in 1781 (Ghosh, 1976). Ruzicka (1891) noted silver impregnation in nucleoli. Association of the secondary constriction regions of the chromosome with the nucleolus was pointed out by Heitz (1931). He termed the regions sine acid thymonucleinico, or SAT regions. Estable and Sotelo (1951) described two components, a filamentous nucleonoma and a structureless pars amorpha, within the nucleolus. Lettré and Siebs (1954) reported the presence of functionally active DNA within the nucleolar filament.

With the advent of the electron microscope, morphological descriptions were refined. The nucleolus is known to be composed of three components: chromatin, the fibrillar component and the granular component (Fig. 2). Approximately 85 to $90 \%$ of nucleolar chromatin is located at the periphery of the nucleolus. The remaining 10 to $15 \%$ is located within the nucleolus. only 0.2 to $1 \%$ of intranuclear DNA consists of rRNA genes.

Pulse labelling with 3 H-uridine and autoradiography demonstrate that the fibrillar component consists of $80 \mathrm{~S}$ ribonucleoprotein (RNP), which contains 45S pre-rRNA (Karasaki, 1965). The granular component consists of RNP particles containing primarily $28 \mathrm{~S}$ rRNA and is derived from the fibrillar component (Recher et al., 1971). The relative size of the fibrillar and granular areas is constant for a given cell type (Hardin et al., 1970), implying that maturation is relatively slow 


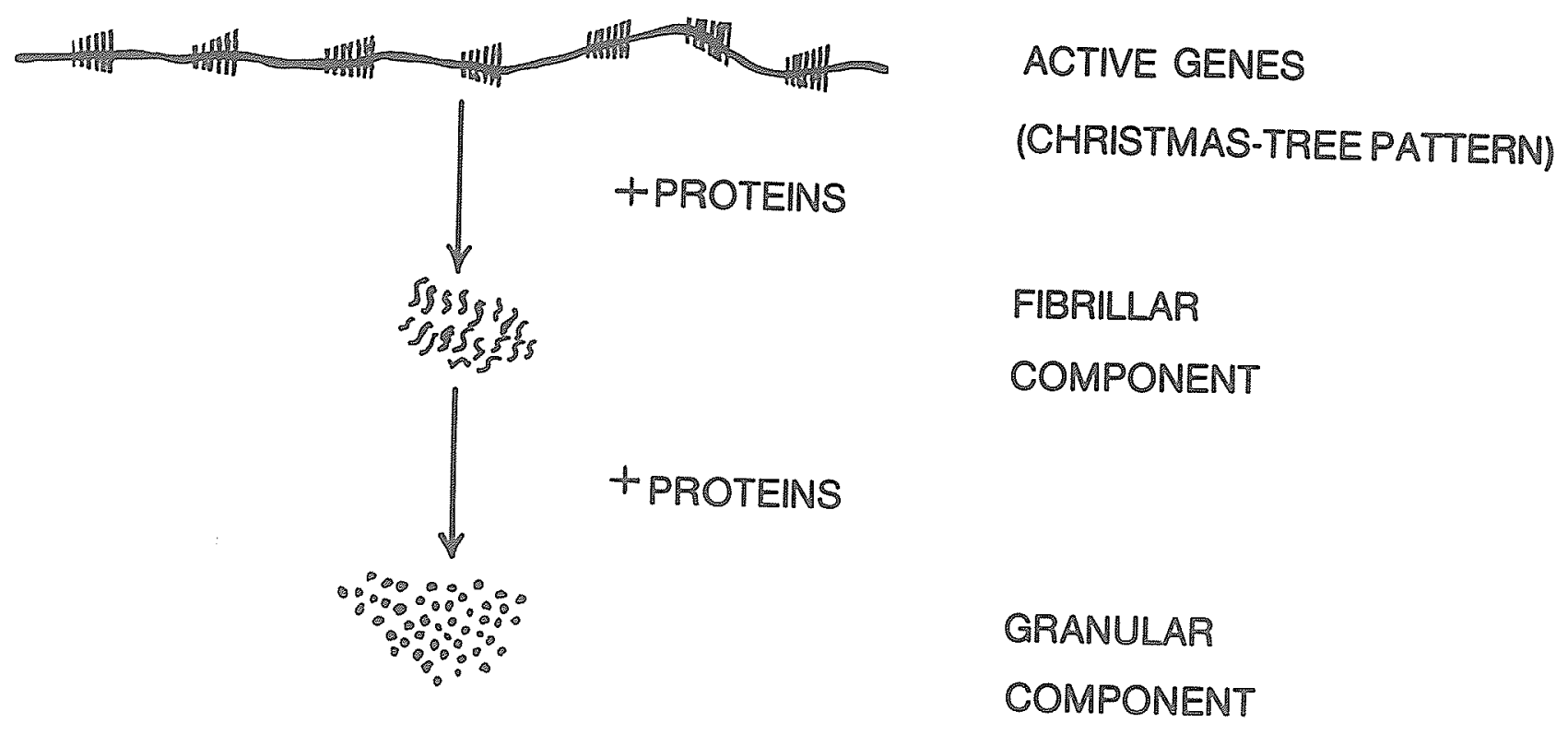

FIG.2 SCHEMATIC PRESENTATION OF NUCLEOLUS. (FROM HADJIOLOV AND NIKOLAEV, 1976)

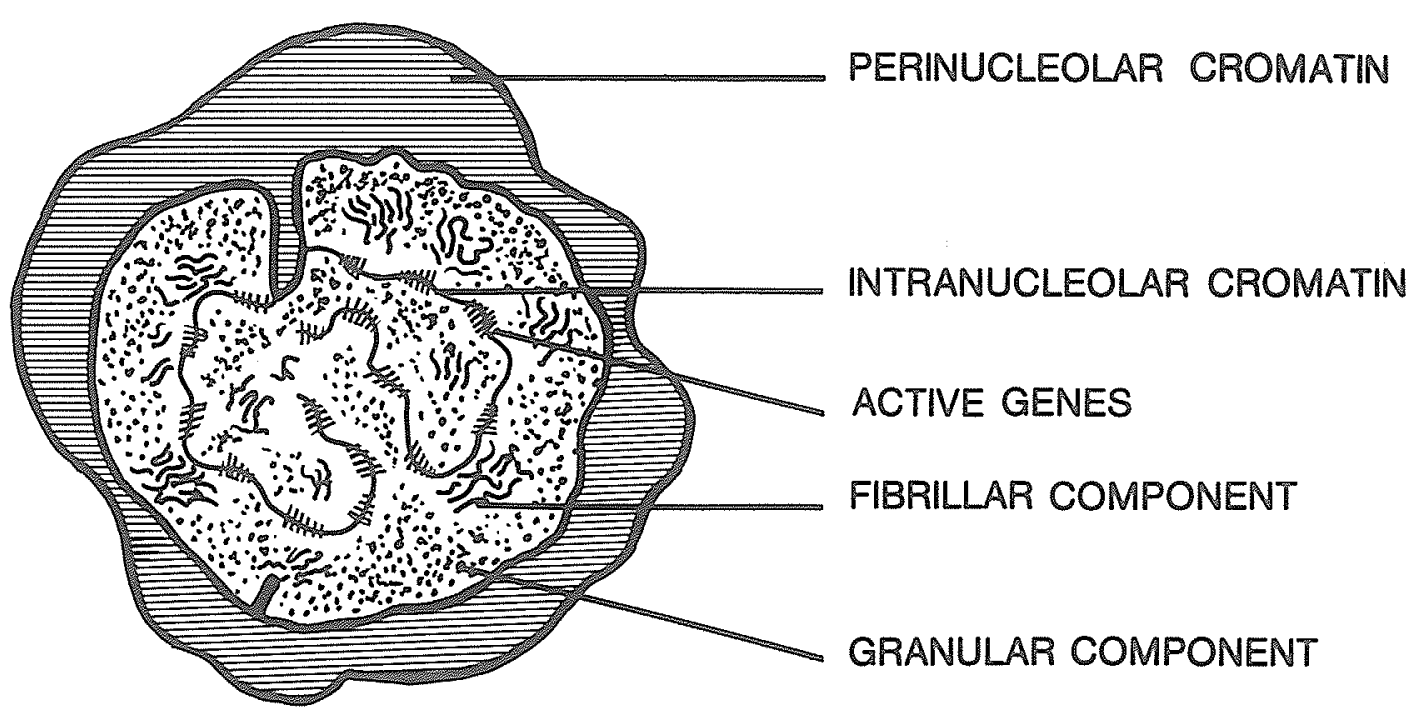


and subject to precise regulation.

Nucleoli appear during telophase and increase in size as the cell produces more RNA. Chromatin from the NORs uncoils and is dispersed within the nucleolus. During prophase the nucleolus disintegrates. If disintegration is late, there is insufficient time for complete condensation of chromatin and the NOR of the metaphase chromosome is usually large (Ghosh, 1976).

Solitary nucleolar DNA fibrils may be visualized after implementing the spreading techniques of Miller and Hamkalo (1972) (Fig.2). The axial fibril of DNA is coated at regular intervals with gradients of short to long matrix fibres, perpendicular to the axis. All units have the same polarity of gradients and are separated by matrix-free segments. This is the classic "Christmas-tree" pattern of active rRNA genes (Miller and Hamkalo, 1972). DNA intervals with matrix fibres are transcribed units and intervals without fibres are non-transcribed spacer units.

Transcribed rRNA units undergo a complex maturation process during which transcribed spacer units are eliminated and numerous RNA-protein interactions occur. Heavy rRNA, sedimenting at 45S, is transcribed at the NOR and interacts with proteins to form the fibrillar component of the nucleolus. This is subsequently degraded via intermediate steps to produce the granular component containing $28 \mathrm{~S}$ and $18 \mathrm{~S}$ rRNA. 
3. Regulation of rRNA production and maturation

The capacity for rRNA production is genetically determined. It has been estimated that this capacity is 15- to 50-fold higher than the consumption of ribosomes (Hadjiolov and Nikolaev, 1976). Critical sites for control of rRNA production in the nucleolus are during transcription, maturation and transportation.

Transcription may be limited by the availability of purine nucleotides or by polymerase A concentrations or activity. A close parallel between the intracellular level of ATP and GTP and the amount of RNA polymerase active in transcription has been reported (Grummt, 1978). As ATP and GTP levels are related to many cellular reactions, the parallel may not be related to the availability of nucleotide pools.

Changes in nucleolar RNA synthesis were correlated with changes in RNA polymerase A activity during transcription (Cooke and Brown, 1973; Grumt, 1978). In contrast, Roeder et al. (1970) found no correlation between levels of enzyme activity and amount or type of RNA synthesis. Spring et a1. (1974) estimated that rDNA is maximally loaded with RNA polymerase, suggesting that post-transcriptional control mechanisms are critical.

Maturation may be controlled at one or more of the RNA-protein interactions. In a given cell type one major pre-RNA maturation pathway occurs, but the RNA cleavage sites may be flexible, resulting in other 
maturation pathways, involving different pre-rRNA molecules. PHA preferentially stimulates one of two maturation paths in lymphocytes (Purte11 and Anthony, 1975). This channelling may be a critical site for qualitative and quantitative regulation of RNP。

Maturation pathways may be influenced by the secondary structure of RNP (Hadjiolov and Nikolaev, 1976). Secondary structure consists of numerous hairpin loops which correspond to G-C rick areas of the transcribed spacer units. Loops could physically direct protein interactions and, as even closely related species have great variability in spacer sequences and secondary structure, cause interspecies and possibly intraspecies variability in ribosome structure. Inspite of the fact that equal amounts of $28 \mathrm{~S}$ and $18 \mathrm{~S}$ RNA are produced, the bulk of the granular component of the nucleolus is $28 \mathrm{~S}$ rRNA. This discrepancy suggests either a great difference in maturation time and/or in speed of migration to the cytoplasm.

The migration of RNP from the nucleolus to the cytoplasm is poorly characterized, though the passage of RNP through the nuclear pore complex has been observed (Bernhard, 1971)。 In heterokaryons, rRNA passage was inhibited until a nucleolus was present and synthesizing RNA. Since the migration of both rRNA and tRNA to the cytoplasm was inhibited after irradiation of the nucleolus (Sidebottom and Harris, 1969), the nucleolus may control the passage of all RNA to the cytoplasm. 
The synthesis of DNA, often triggered by physiological stimuli, may be coordinated in the nucleolus. Blockage of rRNA synthesis with low doses of AMD, prohibit DNA synthesis by indirectly regulating DNA polymerase production (Cooper, 1972). The period of greatest sensitivity is early during activation, long before DNA polymerase synthesis begins. 


\section{Ribosomes}

Ribosomes are large complex organelles, which probably change in shape and protein content at different stages of protein synthesis (Brimacombe, 1976). Each ribosome consists of a large and a small RNP subunit. In eukaryotes, the smaller subunit contains 20 to 30 proteins, dependent on the species, and a 18S rRNA molecule. Larger subunits contain 30 to 40 proteins, one 28S RNA, and one 5S RNA molecule. Few of the proteins are present in multiple copies.

In every cell, ribosomes translate mRNA to produce proteins. The concept that an excess of stable ribosomes is involved in translating a fluctuating level of mRNA is oversimplified. In eukaryotes, the control of ribosome biogenesis is more rapid and versatile than mRNA or tRNA formation. Serum growth stimulation of contact inhibited. mouse fibroblast resulted, within 2 hours, in a 2 -to 3 -fold increase in protein synthesis and formation of new ribosomes, while mRNA synthesis increased only 20 to 30\% (Rudland et al., 1975). During metaphase, protein synthesis decreases to $20-40 \%$ that of interphase. This cannot be explained by a decrease in mRNA, but is associated with a rapid disappearance of polyribosomes. Synthesis of new RNA is not necessary for protein synthesis to increase in interphase (Hodge

et al., 1969). Changes in cell biosynthetic pathways often result in old ribosomes being degraded and new ribosomes being formed (Grasso and Woodard, 1966; Cocucci and Sussman, 1970). This suggests that 
ribosomes are heterogeneous and that special classes of ribosomes may fulfill different functions.

Crick (1968) suggested that the primitive apparatus for protein synthesis might have originally consisted only of RNA, and that the addition of proteins during evolution refined the machinery. No essential differences have been found in the basic functions of ribosomes, however the greater complexity of architecture of eukaryote ribosomes supports the idea that the realization of genetic information may be at the ribosomal level.

Existing ribosomes respond to requirements for increased protein synthesis by increasing their efficiency and by decreasing ribosome degradation. Approximately $70 \%$ of resting lymphocytes are not engaged with mRNA in protein synthesis. After PHA addition, only $30 \%$ are not engaged (Cooper, 1972). The degradation of significant portions of rRNA is reversed after PHA stimulation of normal lymphocytes (Cooper and Gibson, 1971). Wastage of rRNA may be a mechanism by which resting cells may quickly shift to rapid growth.

The increased utilization of pre-existing ribosomes is inadequate for normal cell growth and mitosis. Blockage of rRNA synthesis prohibits DNA synthesis and thus cell division. 


\section{E. Silver Nitrate Reaction}

\section{History}

The reaction of the nucleolus to silver nitrate was observed almost 100 years ago by Ruzika (1891). Cajal (1910) (Schwarzacher et al., 1978) described the silver stained granula of the nucleolus. Estable and Sotelo (1951) described a nucleonema of silver positive

fibrils. Lettré and Siebs (1954) and Lettré et a1. (1966) described this network as silver positive granules around a backbone of the chromosomal NORs. This view was confirmed with electron microscope observations (Schwarzacher et al., 1978). Cellular reactions with silver nitrate have recently gained interest because it was found that NORs react (Goodpasture and Bloom, 1975).

\section{Location and molecular basis of reaction}

Colourless silver nitrate is differentially reduced at the chromosomal locations of rDNA to form a black precipitate. In maximally activated cells of a given type, the degree of silver nitrate precipitation is characteristic of an individual chromosome, and this characteristic is an inherited property (Markovic et al., 1978; Mikelsaar et al., 1977). Silver nitrate reactivity is associated with actively transcribing rDNA cistrons in the fibrillar region of the nucleolus. As it is not located in the granular component, the reactive 
substance is not part of the RNP particle.

Silver nitrate reacts with chromosomal proteins rather than rDNA. Digestion of DNA or RNA does not inhibit the reaction, whereas treatment with trypsin or pronase does (Goodpasture and Bloom, 1975). Hubbell et al. (1979) isolated the protein involved, and found it associated with actively transcribing cistrons of the fibrillar region. Histochemical studies indicate that the interactions of silver ions with carboxyl groups of acidic proteins are primarily responsible for the selective silver staining (Olert et a1., 1979).

\section{Silver reactivity represents rRNA activity}

Silver reactivity is indicative of activity rather than the presence of rRNA genes. This is supported by the following three observations.

In mouse-human somatic hybrid cells, where expression of human rRNA genes was suppressed, only mouse NORs reacted with silver nitrate (Miller et al., 1976a). In mouse-human hybrid cells, where expression of mouse rRNA genes was suppressed, only human NORs reacted with silver nitrate (Miller et al., 1976b).

The pattern of rRNA synthesis during male gametogenesis. (Tres, 1975) and during PHA induced transformation of Iymphocytes (Cooper, 1972) followed that of silver precipitation (Engel et a1., 1977). 
In Xenopus embryos, rRNA synthesis was demonstrated after early gastrula (Brown and Littna, 1964) at which time silver precipitation was first detected (Engel et al., 1977).

The coefficient of correlation between the intensity of silver reactivity and uridine incorporation after inhibition of rRNA with low doses of AMD was 0.99 and 0.96 (Hofgärtner et al., 1979). This almost precise correlation demonstrated that the amount of silver reactivity in the nucleolus is a measure of the functional activity of rRNA genes. 
III. ROLE OF IONS IN REGULATION OF IDNA ACTIVITY

\section{A. Genera1}

Ions are known to exert a profound influence on such varied cellular processes as cell motility, muscle contraction, nerve impulse transmission, endocytosis and exocytosis. The stringent control under which ionic levels are maintained, emphasizes their importance to the cell. Ions dynamically respond to physiological stimuli and either inhibit or activate biochemical reactions. A high degree of specificity of action can be achieved if ionic species are combined or modulated by proteins.

\section{B. Potassium $\left(\mathrm{K}^{+}\right)$}

Potassium is a universal requirement for the growth of cells and is closely monitored by all cells. Levels are influenced by corticosterone, cortisol, deoxycorticosterone, and aldosterone.

A dynamic equilibrium exists between $\mathrm{Na}^{+}$and $\mathrm{K}^{+}$fluxes. Within minutes after the addition of PHA to cultured lymphocytes, $\mathrm{K}^{+}$influx doubles (Quastel and Kaplan, 1970b). The concentration of cellular $\mathrm{K}^{+}$does not change with stimulation since an increased eflux balances the influx (Hamilton and Kaplan, 1977). As mitogens cause human lymphocyte membranes to be extremely leaky to ions in general, it is not surprising that $\mathrm{K}^{+}$influx doubles. 
The extracellular concentration of $\mathrm{K}^{+}$affects the intracellular level. Negendank and Shaller (1979) equilibriated human Iymphocytes in a range of external $\mathrm{K}+$ levels, and found that as external $\mathrm{K}^{+}$levels increased linearly, internal $\mathrm{K}^{+}$levels increased rapidly in a sigmoidal fashion.

Low cellular $\mathrm{K}^{+}$inhibits protein synthesis by limiting the transfer of amino acids from aminoacyl soluable RNA to polypeptides (Lubin and Ennis, 1964). When cell $\mathrm{K}^{+}$fell below 60 to $80 \%$ of control levels, protein synthesis decreased in proportion to further decreases of $\mathrm{K}^{+}$(Ledbetter and Lubin, 1977). Such dramatic changes are not known to occur during normal cellular processes.

Low cellular $\mathrm{K}^{+}$does not inhibit RNA synthesis (Lubin and Ennis, 1964; Pollack and Fisher, 1976). Oubain, a specific inhibitor of the $\mathrm{K}^{+}$site of membrane $\mathrm{Na}^{+} \mathrm{K}^{+}-\mathrm{ATP} a \mathrm{se}$, inhibited PHA stimulation of lymphocytes. $\mathrm{K}^{+}$reversed this inhibition (Quastel and Kaplan, 1970a)。 Thus $\mathrm{K}^{+}$may be implicated in activation of lymphocytes.

The degree of chromosome swelling is affected by $\mathrm{Na}^{+}$and $\mathrm{K}^{+}$ levels, and this is correlated with changes in the capacity of chromosomes to support RNA synthesis (Lezzi, 1970). $\mathrm{Mg}^{++}$and $\mathrm{Ca}^{++}$ amplify the difference between the effects of $\mathrm{Na}^{+}$and $\mathrm{K}^{+}$. 


\section{Magnesium $\left(\mathrm{Mg}^{++}\right)$}

Free $\mathrm{Mg}^{+}$in tissues of rat remains relatively constant at about $1 \mathrm{mM}$. There is little or no concentration gradient between extracellular and intracellular compartments (Bygrave, 1978b). Increasing extracellular $\mathrm{MgCl}_{2}$ from 1.2 to $2.5 \mathrm{mM}$ rapidly stimulated DNA synthesis and mitotic activity of rat thymocytes (Whitfield et al., 1969a). Reducing $\mathrm{Mg}^{++}$to $20 \%$ of normal caused considerable change in growth rate of lymphoblasts, while a reduction to less than $2 \%$ of normal $\mathrm{Ca}^{+1}$ was necessary to affect the growth rate (Owens et a1., 1958).

The lack of hormones and other mechanisms to control the levels of $\mathrm{Mg}^{++}$, make it unlikely that $\mathrm{Mg}^{++}$plays a prominent role in cell regulation. $\mathrm{Mg}^{++}$is important in maintaining the functions of many enzymes including RNA polymerase A, adenylate cyclase, and $\mathrm{Ca}^{+}$transport ATPases. Since the function of $\mathrm{Ca}^{++}$and $\mathrm{Mg}^{++}$are intertwined, $\mathrm{Mg}+$ deprivation can inhibit responses to a $\mathrm{Ca}^{+}{ }^{+}$surge (Whitfield et al., 1979). 
D. Calcium $\left(\mathrm{Ca}^{++}\right)$

Calcium has long been known to influence many biological processes including cell motility, muscle contraction, endocytosis, exocytosis, chromosome movement, neurotransmitter release, microtubule assembly and disassembly, cellular adhesion, cytoplasmic streaming, metabolism of carbohydrates and fats, and others. More recently, $\mathrm{Ca}^{++}$and the hormones which control its levels were found to initiate DNA synthesis and mitosis in the bone marrow, liver and thymus cells of the rat (Whitfield, et al., 1979). Tumor cell proliferation is characterized by not being influenced by $\mathrm{Ca}+$.

According to the three messenger concept, the major regulators of cell activity are hormones, cyclic nucleotides and $\mathrm{Ca}^{++}$(Cheung, 1980). These function as messenger molecules which transduce chemical messages into messages which control one or more critical biochemical reactions. Messengers are interrelated and complement each other with respect to the distance the message travels, the speed and the duration of response. Hormones are the intercellular regulators while cyclic nucleotides and $\mathrm{Ca}^{++}$are the intracellular regulators. Hormones serve as the first messenger, cAMP the second and Cattthe third. Many hormones, such as epinephrine, PGE, vasopressin, and parathyroid hormone interact with receptor sites on the cell membrane and elicit rapid increases in intracellular cAMP and stimulation of DNA synthesis and mitosis. Almost every hormone system 
has an absolute requirement for exogenous $\mathrm{Ca}^{+}$(Rasmussen, 1970)。 Hormones which regulate $\mathrm{Ca}^{++}$(Calcitonin; $1 \propto, 25(\mathrm{OH})_{2}$ vitamin $\mathrm{D}_{3}$; parathyroid hormone) are also major regulators of DNA synthesis and mitotic activity. The existence of such hormones emphasizes the importance of $\mathrm{Ca}^{++}$levels in biological systems. Stimulation of cell membrane adenylate cyclase by a hormone leads to an increase in cellular cAMP. In turn, cAMP functions by stimulating various protein kinases. A striking parallel exists between extracellular $\mathrm{Ca}^{++}$concentrations, cellular cAMP, level of DNA synthesis and cell proliferation (Whitfield et al., 1973)。 Since $\mathrm{Ca}^{++}$inhibits adenylate cyclase (Whitfield et al., 1973), $\mathrm{Ca}^{++}$stimulation of CAMP was not understood until the intimate relationship of $\mathrm{Ca}^{+t}$ and calmodulin was discovered (Reviewed by Cheung, 1980)。

Calcium exists in many forms. These include exchangeable, non-exchangeable, free (ionized), diffusable but complex, and bound and precipitated in mineral form. The ionized form is biologically the most active and this is a small portion of the total calcium (Bygrave, 1978a).

There is a steep, $10^{4}$-fold gradient between intracellular (0.1.M M) (Sulakhe and St. Louis, 1980) and extracellular ( $>1.0 \mathrm{mM}$ ) (Whitney and Sutherland, 1972) Cat+ levels. Cells work unceasingly to keep this gradient. Passive influxes of $\mathrm{Ca}^{+}+$are determined by 
the concentration gradient and by membrane permeability. At least 3 separate "gates" by which $\mathrm{Ca}^{++}$enters, exists. One of which is independent of membrane potential and possibly dependent on hormone activation (Sulakhe and St. Louis, 1980). Ca+t eflux is active and probably consists of two separate mechanisms: a Catt regulated ATPase and a $\mathrm{NA}^{+}-\mathrm{Ca}+$ exchange system. Basal rates of transmembrane fluxes do not vary greatly with cell type (Claret-Berthon et al., 1977).

The distribution of $\mathrm{Ca}^{++}$is heterogenous and fluxes are a vital component of physiological responses of cells. Uneven distribution is maintained by specific calcium transport systems, and by the specificity of $\mathrm{Ca}^{+H}$ binding to oxyanions, such as carboxylates and phosphates. (Bygraves, 1978a). Claret-Berthon et al. (1977) analysed rat liver cells and found the following three major exchangeable pools of $\mathrm{Ca}+$.

The first compartment contained rapidly exchangeable Ca+t (4 min.) and was identified as extracellular Cat bound loosely to the cell membrane. The Cat+ chelator, EGTA, which does not penetrate the cell membrane, completely displaced $\mathrm{Ca}^{++}$from this compartment.

The second compartment contained less rapidly exchangeable $\mathrm{Ca}^{++}$ (16 min.) and was identified as intracellular Cat+. It was comprised of Catt pools in the mitochondria, endoplasmic reticulum and associated with proteins. Since $30 \%$ of intracellular $\mathrm{Ca}^{++}$was sequestered in 
the mitochondria, it is evident that these organelles play an important role in cellular $\mathrm{Ca}^{++}$homeostasis.

The third compartment consisted of slowly exchangeable $\mathrm{Ca}^{++}$ (22.3 min。), which was identified as consisting at least partly of extracellular $\mathrm{Ca}^{+}$in intimate contact with the cell membrane. EGTA displaced about $85 \%$ of this $\mathrm{Ca}++$. With the addition of the $\mathrm{Ca}^{+}$displaced from the first compartment, EGTA displaced $63 \%$ of total exchangeable $\mathrm{Ca}+$.

Calcium ions are able to regulate many diverse and complicated cellular processes by activating Cat-binding proteins, such as troponin $\mathrm{C}$ and calmodulin. Proteins bind $\mathrm{Ca}^{++}$, selectively and reversibly, at their carboxylate groups causing conformational changes, which offer great potential for regulating a wide variety of cellular processes.

Most regulatory roles previously attributed to free $\mathrm{Ca}^{++}$, require its association with calmodulin (Means and Dedman, 1980). Calmodulin itself is not active. Binding with $\mathrm{Ca}^{+}$results in an active, more helical molecule (Liu and Cheung, 1976; Dedman et al., 1977) which binds to an apoenzyme to form a holoenzyme. The specificity of $\mathrm{Ca}+$ action is through calmodulin binding with other proteins. Calmodulin is an important link between $\mathrm{Ca}^{++}$and CAMP. It regulates $\mathrm{Ca}^{+}$-dependent adenylate cyclase, which explains why 
exogenous $\mathrm{Ca}^{+t}$ could cause a cAMP surge, while $\mathrm{Ca}^{+4}$ alone inhibits adenylate cyclase (Whitfield et al., 1979). Another link exists controlling $\mathrm{Ca}^{++}$efflux. Membrane associated $\mathrm{Ca}{ }^{++}$pump acitivity is likely modulated by calmodulin and cAMP-dependent protein kinase(s) (Sulakhe and St. Louis, 1980).

Calmodulin has a striking lack of tissue or species specificity. It has been structurally conserved throughout the animal and plant kingdoms (Cheung, 1980). The protein shares a large homology with troponin C. It is characterized by thermal stability and abundant acidic amino acids which furnishes carboxylate groups for the reversible binding of $\mathrm{Ca}^{++}$(Cheung, 1980).

Harper et al. (1980) reported labelling of the nucleus of rat liver and adrenal cortex cells with antibody for calmodulin. The amount of labelling varied as a function of hormonal activity and was in a pattern consistent with nucleolar organization. Calcium is essential for the mitogenetic effects of PHA (Alford, 1970; Whitney and Sutherland, 1972). The removal of $\mathrm{Ca}^{++}$with citrate inhibited transformation (Alford, 1970). This inhibition was totally reversed by restoring $\mathrm{Ca}+$ within 18 hours after the addition of PHA, before DNA synthesis began. As the removal of Cat+ after DNA synthesis began, did not alter nucleic acid synthesis, the action of $\mathrm{Ca}+\mathrm{t}$ is not directly on DNA synthesis. Whitney and Sutherland (1972) added EGTA at progressively later times after PHA, 
and found that for the first 12 hours, the amount of DNA synthesis progressively increased as the time lapse between adding EGTA to PHA stimulated cells increased. Later additions of EGTA did not produce any inhibition.

EGTA also inhibited PHA stimulation of RNA synthesis, an event which occurs early during transformation. Increasing concentrations of EGTA from 0 to $1.48 \mathrm{mM}$ progressively inhibited RNA and DNA synthesis in PHA stimulated lymphocytes (Whitney and Sutherland, 1972). Cooper (1971) proposed that the direct effect of $\mathrm{Ca}^{++}$on early RNA synthesis could control transformation. Within five minutes after PHA stimulation of lymphocytes a brief influx of $\mathrm{Ca}^{++}$occurs, along with other ions. The influx is not thought to initiate transformation as lowering extracellular $\mathrm{Ca}^{++}$levels long after this surge subsided still prevented the initiation of DNA synthesis (Whitfield et al., 1979). Also, under conditions which ionophore A23187 did not cause Cat to enter the cell, DNA synthesis was triggered (Rosenstreich and Blumenthal, 1977; Gemsa et al., 1979).

Exogenous $\mathrm{Ca}^{+}$directly stimulates DNA synthesis of rapidly responding thymic lymphocytes (Whitfield et al., 1980). Raising the Catt concentration to $1.5 \mathrm{mM}$ for 5 minutes to 5 hours, stimulated an increase in synthesis of CAMP and DNA synthesis. Pretreatment with parathyroid hormone enabled small increments $(0.02$ to $0.6 \mathrm{mM})$ of $\mathrm{Ca}^{++}$to stimulate both CAMP and thymic Iymphocyte proliferation. 
Similarly, increasing extracellular Cat of liver cells from 2.3 to $14 \mathrm{mM}$ resulted in increased protein, RNA and DNA synthesis (Anghileri and Heidbreder, 1978)。

Reducing blood $\mathrm{Ca}^{++}$levels of rats by removing the parathyroid gland and by reducing dietary intake, almost immediately reduces cell proliferation in the bone marrow and thymus. Proliferation can be induced by injection of parathyroid hormone or $\mathrm{CaCl}_{2}$ (Perris et al. $; 1967)$.

The proliferation of neoplastic cells is distinguished by not being controlled by $\mathrm{Ca}^{++}$. Such cells can proliferate in low $\mathrm{Ca}^{++}$ media $(0.001$ to $0.1 \mathrm{mM}$ ) (Whitfield et al., $1979 \& 1980$ ) and their mitochondria tend to sequester and retain $\mathrm{Ca}^{+}$, resulting in low cytoplasmic levels (Owens et al., 1958). The key to understanding and controlling autonomous proliferation of cancerous cells could possibly be found after there is a better understanding of the role of $\mathrm{Ca}+$ in non-cancerous cells. 
MATERIALS AND METHODS

\section{MATERIALS}

\section{A. Lymphocytes}

Human peripheral blood, collected in heparinized vacutainer tubes was utilized.

\section{B. Culture Media}

Cells were cultured in McCoy's 5A medium (modified) with 10\% fetal calf serum (FCS), except where otherwise indicated. Custom formulated McCoy's 5A (modified) media without $\mathrm{KCl}$, and without $\mathrm{MgSO}_{4}$ were utilized for $\mathrm{K}^{+}$and $\mathrm{Mg}^{++}$reduced experiments.

C. EGTA (Ethyleneglycol-bis-(B-amino-ethyl ether) $N, N^{1}-$ tetra-acetic) (MW-380.4)

A stock solution of $7.2 \mathrm{mM} / \mathrm{cc}$ was prepared by adding enough medium to $136.8 \mathrm{mg}$ EGTA, to produce 10cc. This was neutralized to pH 7 with $\mathrm{NaOH}$ to dissolve the EGTA. The solution was sterilized with a millipore filter.

\section{Calmodulin (CDR)}

Calmodulin was gratefully received from Dr. M.S. Nijjar, Department of Pathology, University of Manitoba. The solution was produced from bovine brain and contained $0.15 \mathrm{mg} \mathrm{CDR} / \mathrm{cc}$. 
II. METHODS

\section{A. Culturing}

Human peripheral blood was collected in heparinized vacutainer tubes and erythrocytes allowed to settle at room temperature for 1 to 2 hours. Plasma $(0.2 c c)$ was added to sterile culture tubes containing $5 \mathrm{cc}$ of $\mathrm{McCoy}^{\mathrm{B}} \mathrm{s} 5 \mathrm{~A}$ medium (modified) with $10 \%$ FCS. This medium contains $5.4 \mathrm{mM} \mathrm{KCl}, 0.8 \mathrm{mM} \mathrm{MgSO} 4,1.8$ $\mathrm{mM} \mathrm{CaCl} 2$, and other essential growth elements. Tubes were incubated at $37^{\circ} \mathrm{C}$ in a $\mathrm{CO}_{2}$ incubator for periods up to 72 hours. Custom formulated McCoy's 5A (modified) media without $\mathrm{KCl}$ and without $\mathrm{MgSO}_{4}$ were purchased. Constant osmolality was maintained by adding $\mathrm{NaCl}$ to $\mathrm{K}^{+}$reduced medium and $\mathrm{MnSO}_{4}$ to $\mathrm{Mg}^{++}$reduced medium. Both formulations contained 10\% FCS, therefore $\mathrm{K}^{+}$reduced medium contained approximately $0.5 \mathrm{mM} \mathrm{K}^{+}$, and $\mathrm{Mg}^{++}$reduced medium contained approximately $0.1 \mathrm{mM} \mathrm{Mg}{ }^{++}$. Since $0.2 \mathrm{cc}$ of human plasma with lymphocytes was added to $5 \mathrm{cc}$ of culture medium for each treatment, the final serum concentration was approximately $14 \%$. $\mathrm{K}^{+}$reduced treatments contained approximately $0.7 \mathrm{mM} \mathrm{K}^{+}$, and $\mathrm{Mg}^{++}$reduced treatments contained approximately $0.14 \mathrm{mM} \mathrm{Mg}+$ 。

Lymphocytes were stimulated with 0.05 cc of phytohaemagglutinin (PHA) per $5 \mathrm{cc}$ of medium. 
B. Harvesting

When mitotic spreads for NOR examination were required, colcemid $\left(5.0 \times 10^{-3} \mu \mathrm{g} / \mathrm{ml}\right)$ was added to prevent spindle formation. Two hours post colcemid, culture tubes were centrifuged at $600 \mathrm{rpm}$ for 5 minutes. The supernatant was discarded and $5 \mathrm{cc}$ of hypotonic KCl $(0.075 \mathrm{M})$ added to the cell suspension. After 10 minutes, the suspension was centrifuged at $600 \mathrm{rpm}$ for 5 minutes. The supernatant was discarded and cells fixed in 3:1 parts methanol-acetic acid for a minimum of 20 minutes. Slides were prepared by dropping the cell suspension from a pasteur pipette held approximately one metre above a wet microscope slide, which had been cooled in ice water. This effectively burst the cell membrane, allowing chromosomes to spread. Cells used for measuring the nuclear diameter and nucleolar silver reactivity were harvested without the addition of colcemid. Tubes were centrifuged at $600 \mathrm{rpm}$ for 5 minutes, the supernatant discarded and cells fixed in 3:1 methanol-acetic acid for a minimum of 20 minutes. Slides were prepared by gently spreading the cell suspension on slides. 

C. Silver Nitrate Treatment (modified from Bloom and

Slides were treated in a humid environment. The environment was prepared by lining the bottom of a petri dish with absorbant towelling to hold moisture. Small rubber rings supported the slides and prevented them from touching the moist bottom. Each slide was flooded with $50 \%$ silver nitrate, covered with a coverslip and the petri dish placed in a $55^{\circ} \mathrm{C}$ oven for 16 to 18 hours. After treatment, slides were washed in running tap water, air dried, placed in xylol for 1 to 2 minutes and mounted in neutral buffered mounting medium.

\section{Evaluation of Nuclear Size and Silver Reactivity}

The first 100 lymphocytes, from 3 different slides of each treatment were evaluated. The nuclear diameter was measured with the aid of an eyepiece micrometer disc and classified as follows:

\section{Nuclear Diameter $(\mu)$}

Sma11:

$\leq 5.0$

Medium:

$5.5-8.5$

Large:

$\geq 9$

Quantification of silver reactivity was more difficult. A combination of measuring the size of the reactive area, counting 
the number of reactive areas and subjective evaluations was used to classify the cells as follows (Figs.3 \& 4):

\begin{tabular}{|c|c|c|}
\hline 0 & - & no reaction \\
\hline $1^{+}$ & - & 1 to 2 small reactive areas \\
\hline $2^{+}$ & - & $\begin{array}{l}\text { several small reactive areas or } \\
\text { one area with a diameter greater } \\
\text { than } 1.0 \mu\end{array}$ \\
\hline $3^{+}$ & - & $\begin{array}{l}5 \text { or more small reactive areas or } \\
\text { one area with a diameter greater } \\
\text { than } 1.5 \mu\end{array}$ \\
\hline $4^{+}$ & - & $\begin{array}{l}\text { a cluster of reactive areas or one } \\
\text { area with a diameter greater than } \\
2 \mu \text {. }\end{array}$ \\
\hline
\end{tabular}

\section{E. Metaphase Examinations}

Twenty metaphase spreads from each of the $\mathrm{K}^{+}$-reduced, the $\mathrm{Mg}^{++_{-}}$ reduced and the EGTA treated cultures were analysed. The Iatter was treated for the last 1/3 (24 hours) of a 72 hour culture period. Cells in metaphase were not observed after longer periods of treatment with EGTA. A total of 526 control metaphase cells were examined. The number of silver reactive NORs (AgNORs) was recorded. 
Figs.3 and 4: Silver reactivity of lymphocytes. The silver reactivity of 1 ymphocytes was graded from $0-4^{\dagger}$, based on the size of the reactive areas. Unstimulated 1ymphocytes were smal1 and had small reactive areas (Fig. 3). PHA stimulated lymphocytes were larger and had larger reactive areas (Fig. 4). 

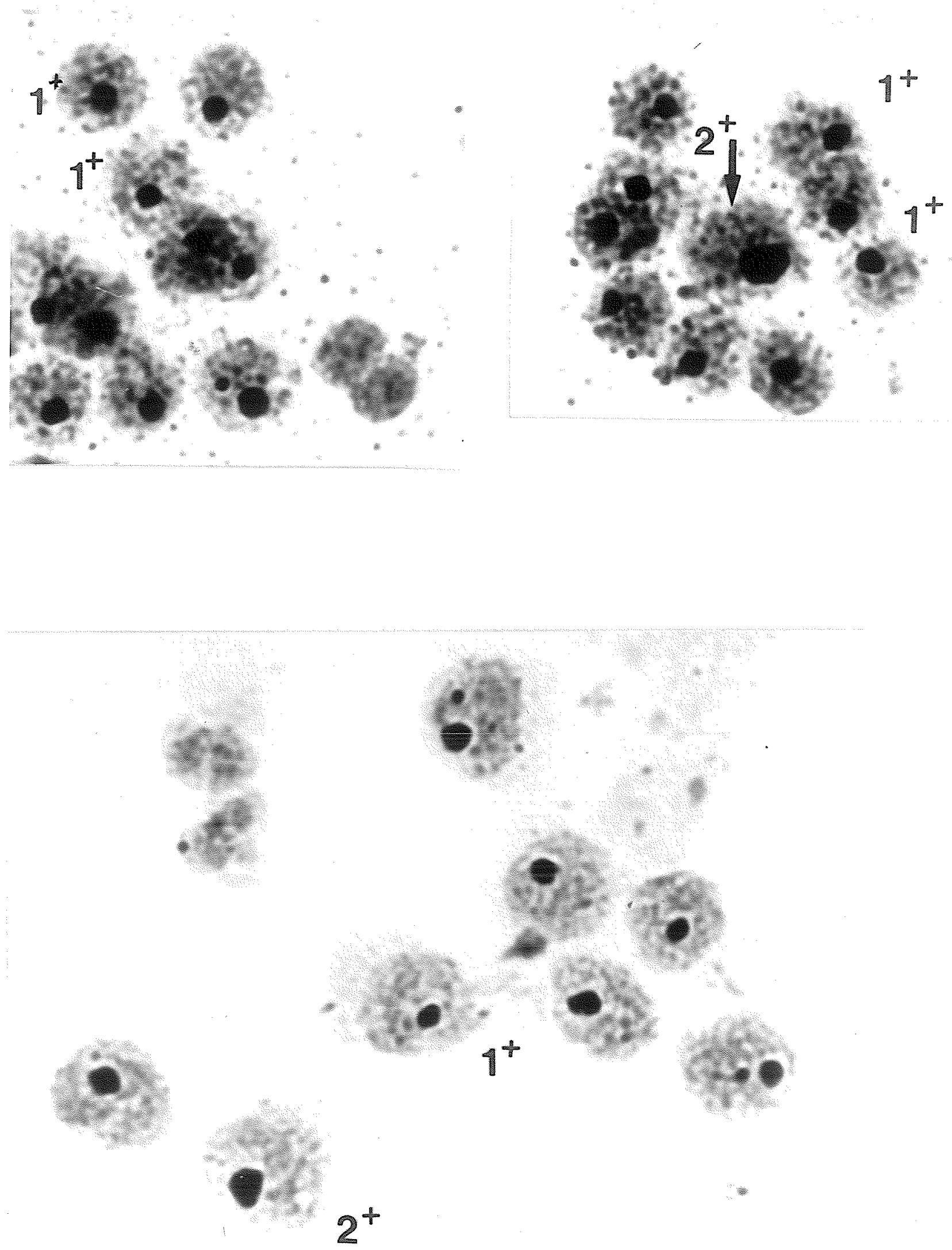

FIG. 3 


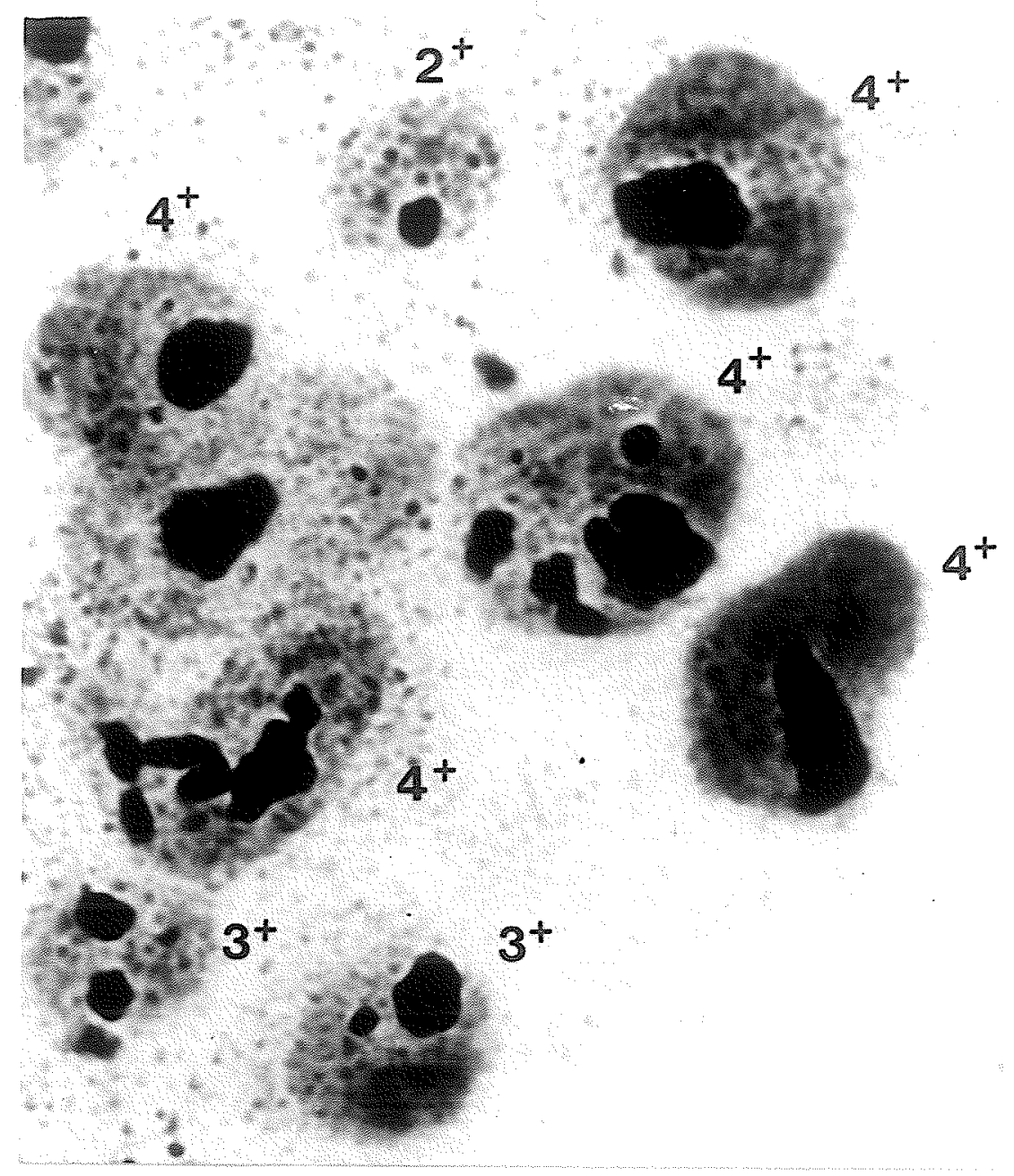

FIG.4
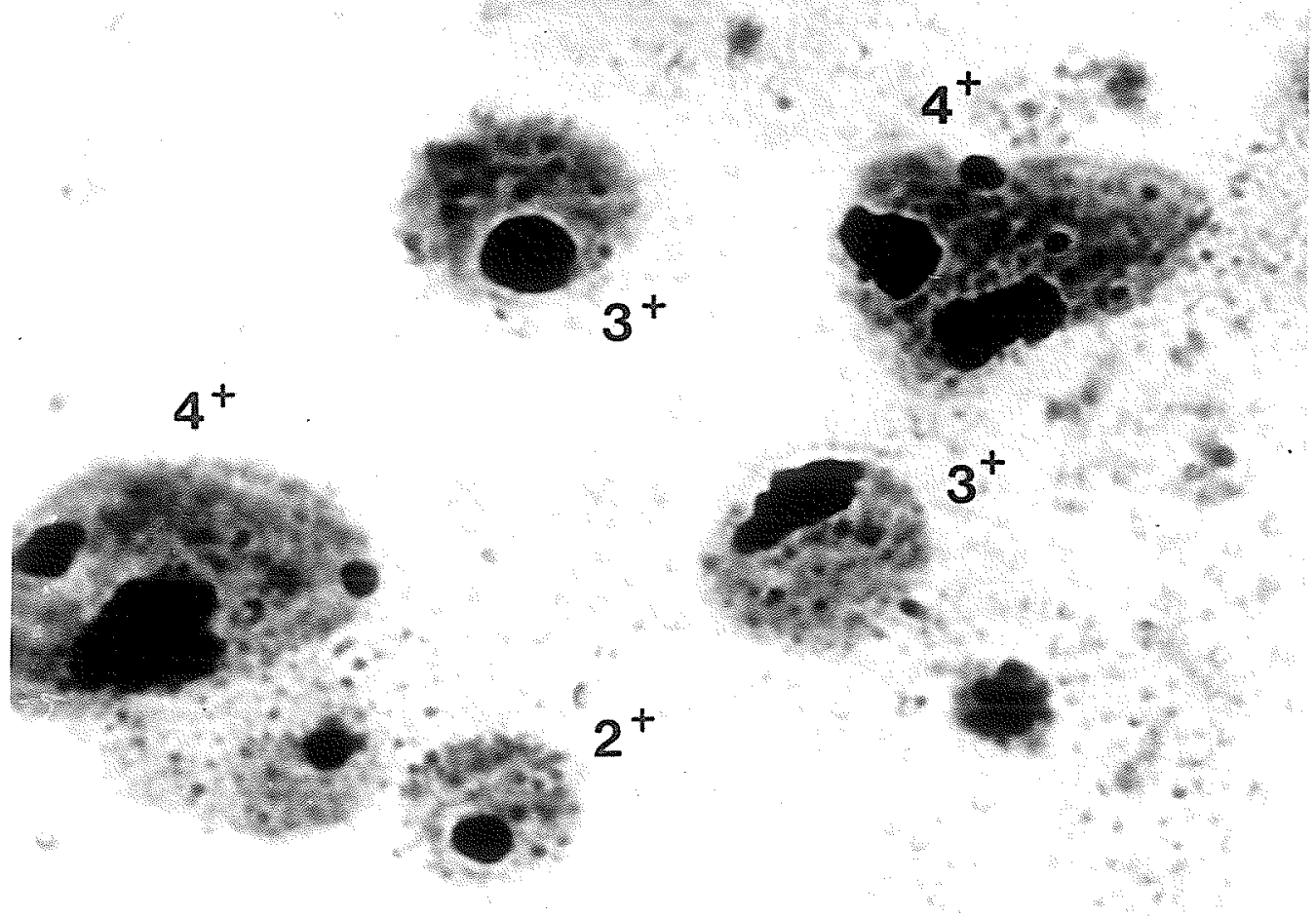
RESULTS

Unstimulated cultured lymphocytes always had a small nuclear diameter and a small silver reactive area (Fig. 3), neither of which increased with time (Fig. 5). After stimulation with PHA the nuclear diameter and nucleolar silver reactivity greatly increased (Figs.4\&5). The peak period of increase was 18 to 48 hours after the addition of $\mathrm{PHA}$. The increase in silver reactivity was linearly related to the log of the nuclear diameter (Fig. 6). Both parameters are indicators of lymphocyte activation.

Lymphocytes were cultured in medium containing a graduation from normal levels of $\mathrm{K}^{+}(5.0 \mathrm{mM})$ and $\mathrm{Mg}^{+}(1.0 \mathrm{mM})$ to $14 \%$ of normal $\mathrm{K}^{+}(0.7 \mathrm{mM})$ and $\mathrm{Mg}^{++}(0.14 \mathrm{mM})$. Removal of up to $86 \%$ of the extracellular $\mathrm{Mg}^{+}$and $\mathrm{K}^{+}$did not affect the silver reactivity, nuclear diameter (Fig. 7), or the mean number of AgNORs (Table I) of PHA stimulated lymphocytes.

$\mathrm{Ca}^{++}$was reduced in the culturing media by chelation with EGTA. Since $1 \mathrm{M}$ EGTA binds $1 \mathrm{M} \mathrm{CaCl}_{2}$, and human McCoy's growth medium has $1.8 \mathrm{mM} \mathrm{CaCl}_{2}$, all $\mathrm{Ca}^{++}$should be bound when the final EGTA concentration is $1.8 \mathrm{mM}$.

When $\mathrm{Ca}^{++}$was chelated with EGTA for the last 24 hours of a 72 hour culturing period, a slight decline in nuclear diameter and silver reactivity was observed (Fig. 8). The decrease was correlated with an increased concentration of EGTA and did not plateau at $1.8 \mathrm{mM}$ 
Fig. 5: Histograms showing changes in a) silver reactivity and b) nuclear diameter of lymphocytes at various times after culturing $i)$ with and $i i)$ without PHA. PHA was added to treated cultures at 0 hour. 
$\%$ OF CELLS

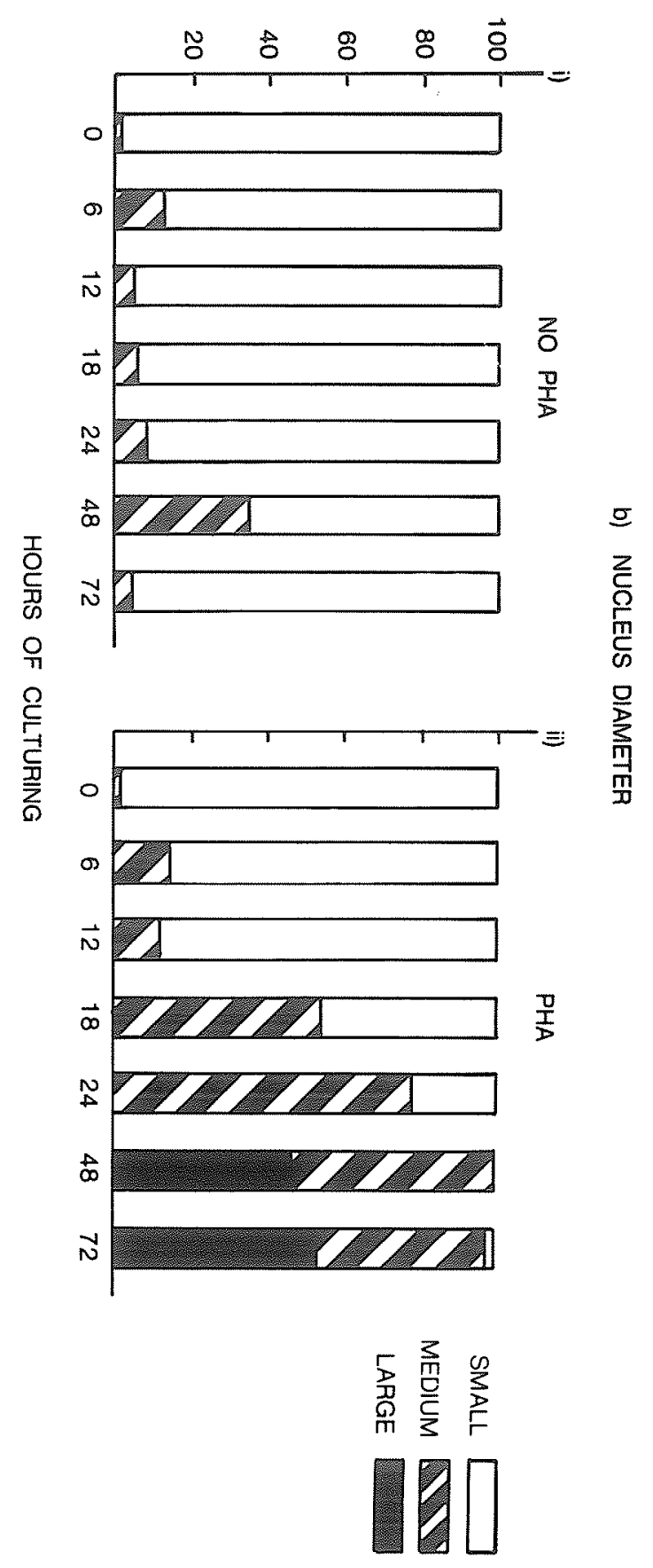

$\%$ OF CELLS

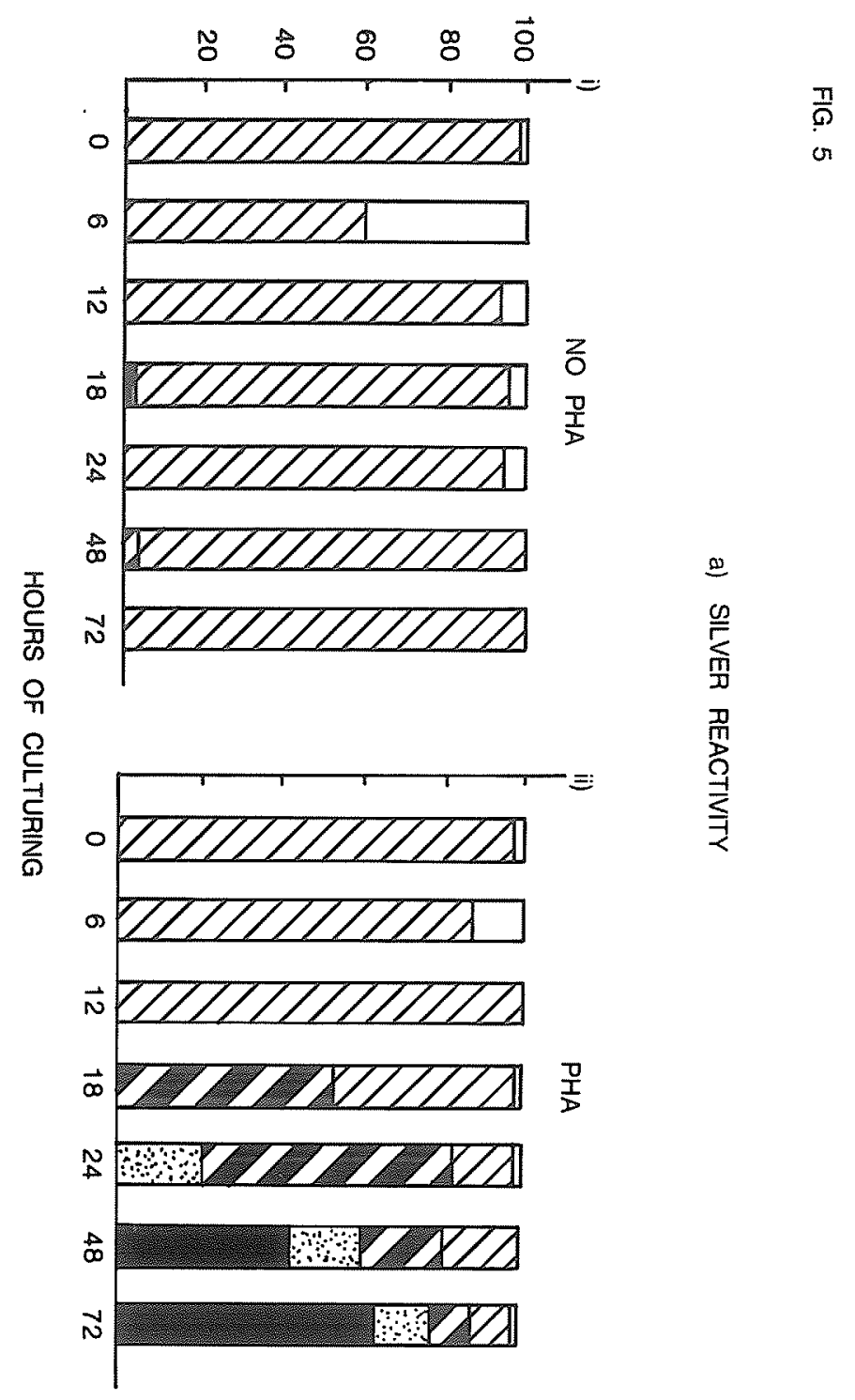


Fig. 6: Relationship of silver reactivity and nuclear diameter of lymphocytes.

Bars represent +1 S.D. 


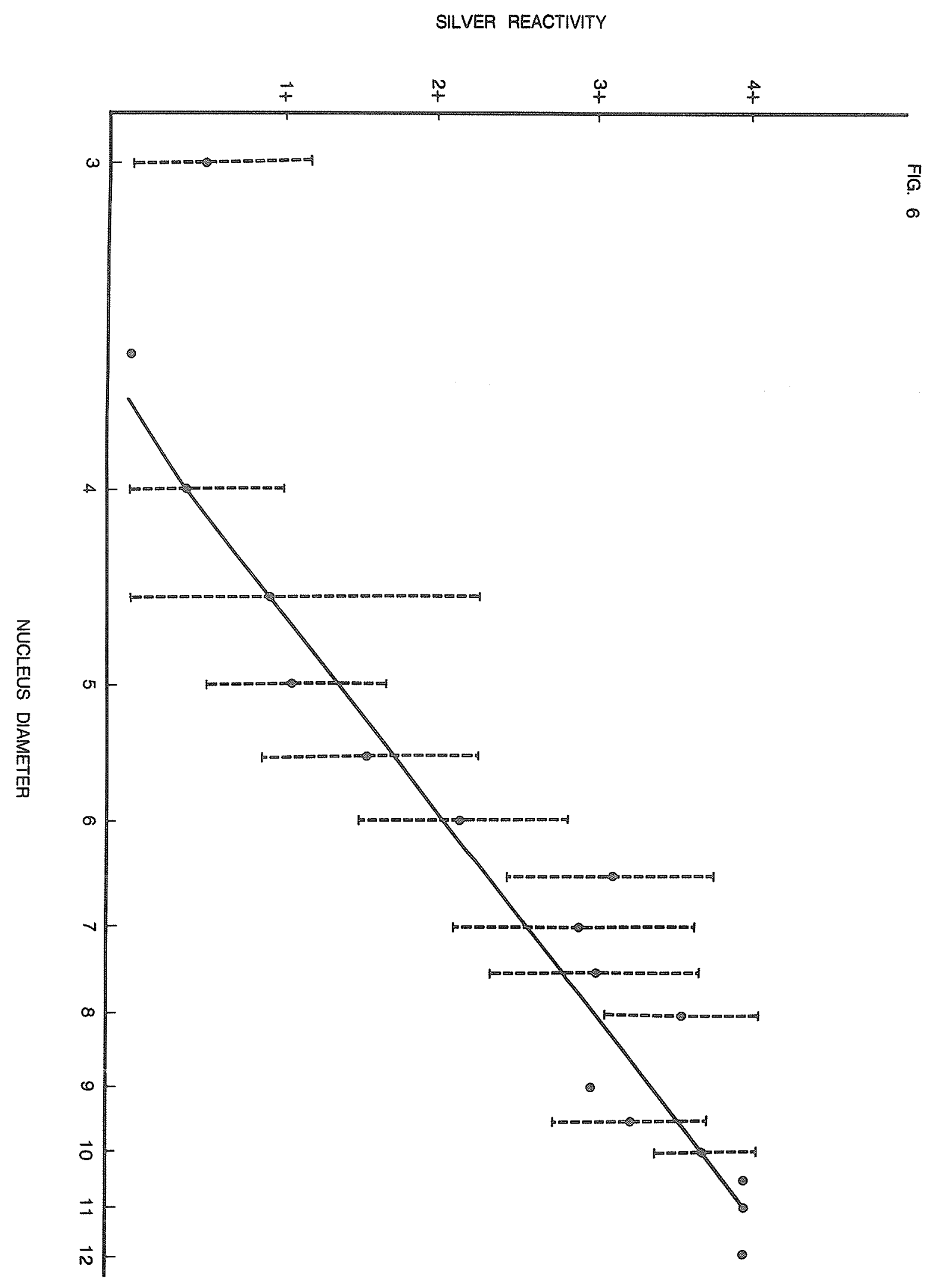


Fig. 7: Histograms showing a) silver reactivity and b) nuclear diameter of Iymphocytes after 72 hours of culturing with various concentrations of i) $\mathrm{K}^{+}$and ii) $\mathrm{Mg}^{++}$. 
\% OF CELLS

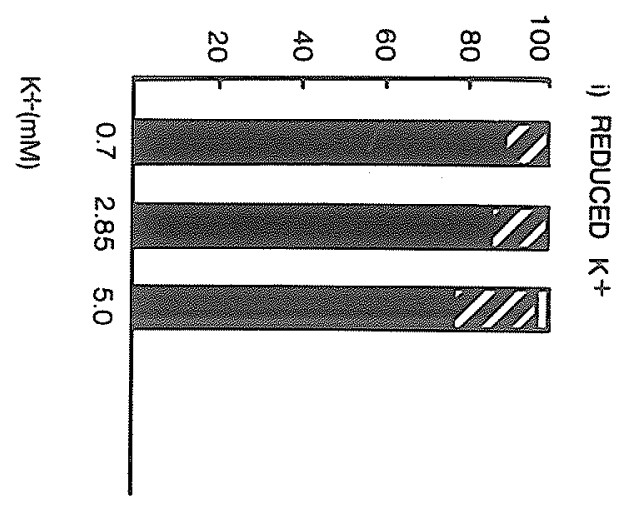

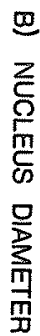

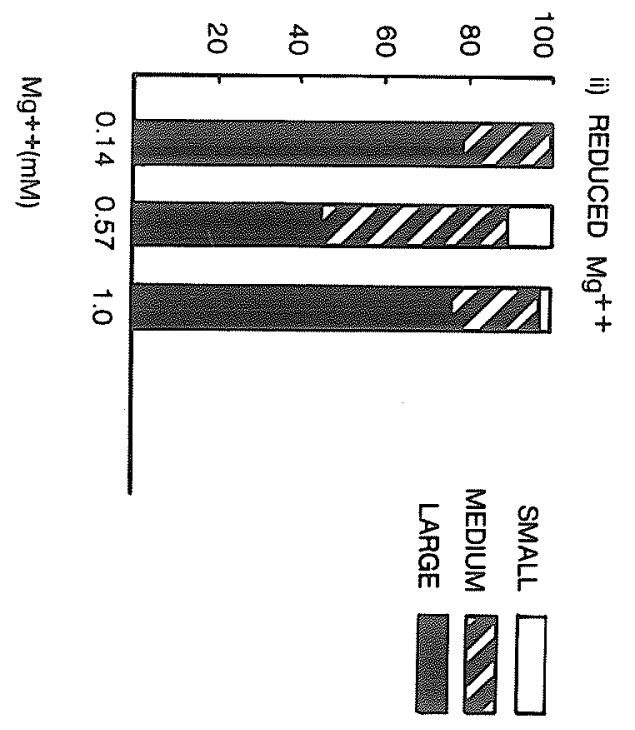

$\%$ OF CELLS

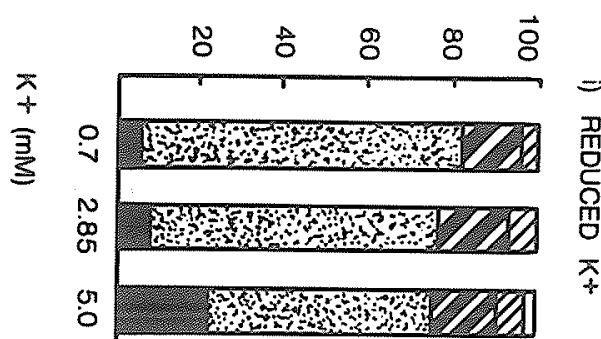

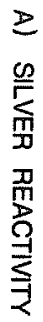

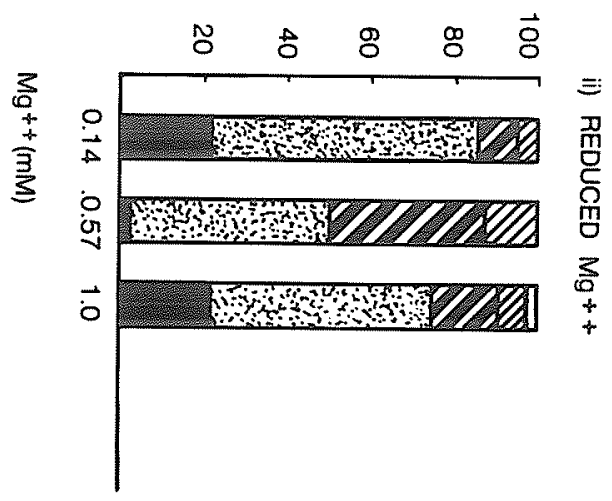


TABLE I

\begin{tabular}{|c|c|c|c|}
\hline Treatment & $\begin{array}{l}\text { Hours of Treatment/ } \\
\text { Hours of culturing } \\
\text { with PHA }\end{array}$ & $\begin{array}{l}\text { Total Number of } \\
\text { Metaphase Cells }\end{array}$ & $\begin{array}{l}\text { Mean Number } \\
\text { of AgNoRs }\end{array}$ \\
\hline Controls & $72 / 72$ & 526 & 7.7 \\
\hline $\begin{array}{l}0.7 \mathrm{mM}^{+} \\
(14 \% \text { of norma1) }\end{array}$ & $72 / 72$ & 20 & 8.0 \\
\hline $\begin{array}{l}0.14 \mathrm{mM} \mathrm{Mg}^{++} \\
(14 \% \text { of normal) }\end{array}$ & $72 / 72$ & 20 & 7.6 \\
\hline $1.8 \mathrm{mM}$ EGTA & Last $24 / 72$ & 20 & 7.5 \\
\hline
\end{tabular}

$4.0 \mathrm{mM}$ EGTA

$72 / 72$

No Mitosises 
Fig. 8: Histograms showing changes in lymphocyte a) nuclear diameter and b) silver reactivity after 24 hours of treatment with EGTA. After 48 hours of culturing, various concentrations of EGTA were added to PHA stimulated lymphocytes and $\mathrm{CaCl}_{2}$ was added to one treatment group. Al1 were harvested at 72 hours. 


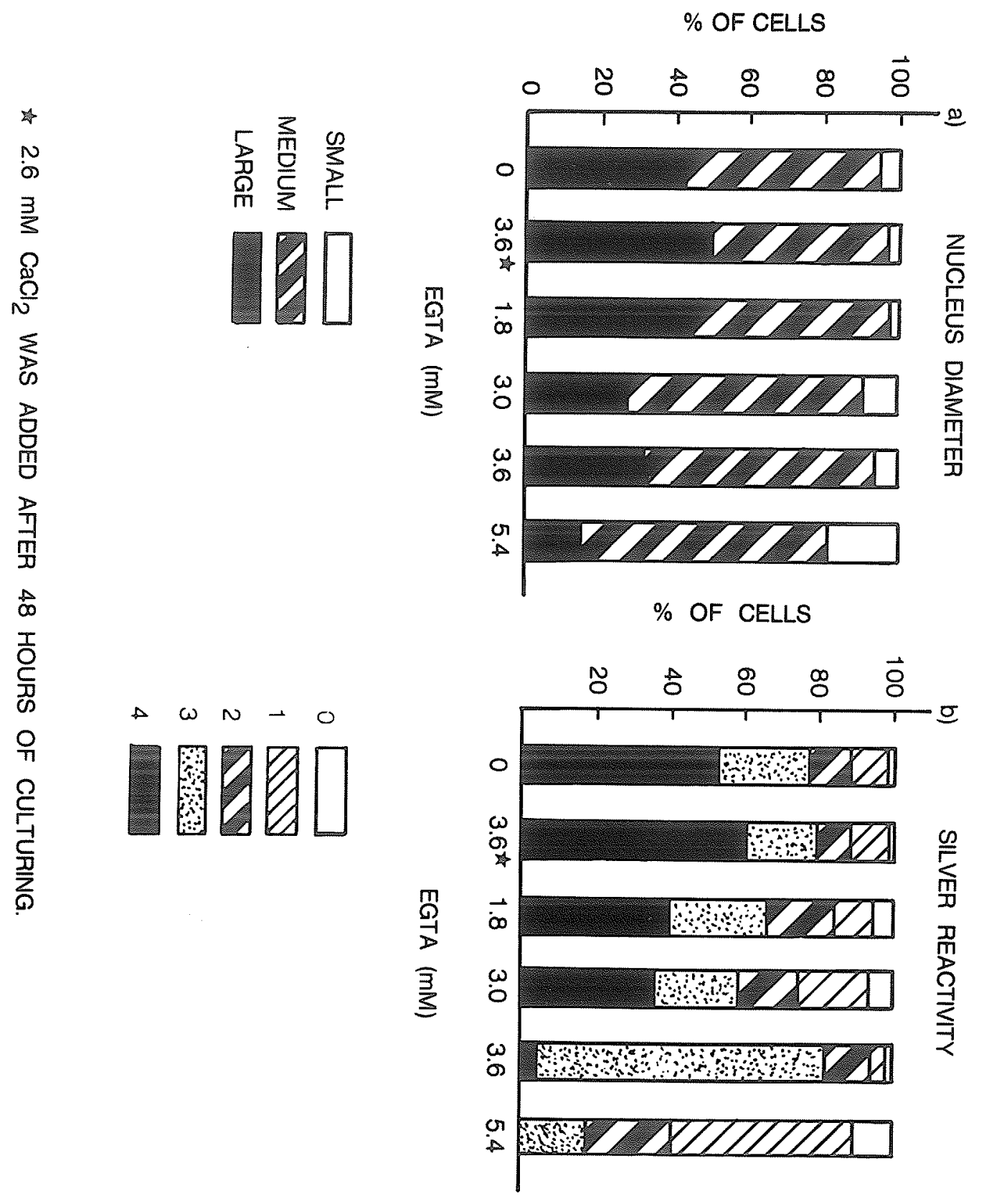


EGTA, the concentration at which all ionized calcium was expected to be chelated. When some $\mathrm{CaCl}_{2}$ was restored to treated cultures, the silver reactivity and nuclear diameter was comparible to control cells, indicating the decrease was not a toxic effect of EGTA. The mean number of AgNORs in lymphocytes treated with $1.8 \mathrm{mM}$ EGTA for the last 24 hours of a 72 hour culturing period was 7.5 per cell (Table I). This did not vary significantly from the control level of 7.7 AgNoRs per cell.

Cells from one treatment group which was treated with $1.8 \mathrm{mM}$ EGTA, for the last 24 hours of a 72 hour culturing period had silver reactive areas dissociating from the nucleolus of interphase cells and NOR of metaphase cells (Figs.9\&10). Dissociated silver reactive areas formed uniform spheres with a ring of satellite bodies composed of RNP-like material. Due to this phenomenon further investigations into the role of $\mathrm{Ca}^{+H}$ in lymphocyte transformation were undertaken. Repetition of the same experiment failed to produce a similar dissociation pattern.

$$
\mathrm{Ca}^{++} \text {was chelated with } 4.0 \mathrm{mM} \text { EGTA for varying periods of time }
$$
during a 72 hour period of culturing PHA stimulated lymphocytes (Fig. 11). The nuclear diameter and silver reactivity was relatively constant, if EGTA ( $4.0 \mathrm{mM})$ was added 48 hours post PHA or later. When EGTA was added 0 to 24 hours post PHA, there was a dramatic reduction in nuclear diameter and silver reactivity. 
Figs. 9 and 10: Lymphocytes with silver reactive areas dissociated from the nucleolus of interphase cells (Figs. 9 and 10a) and the NORs of metaphase cells (Fig. 10b). 
e

a

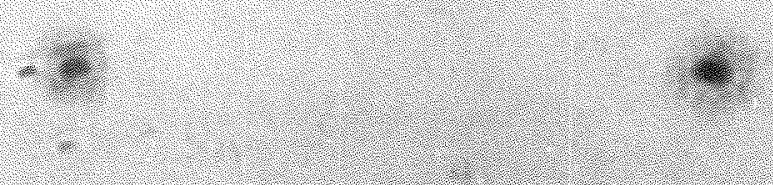

क

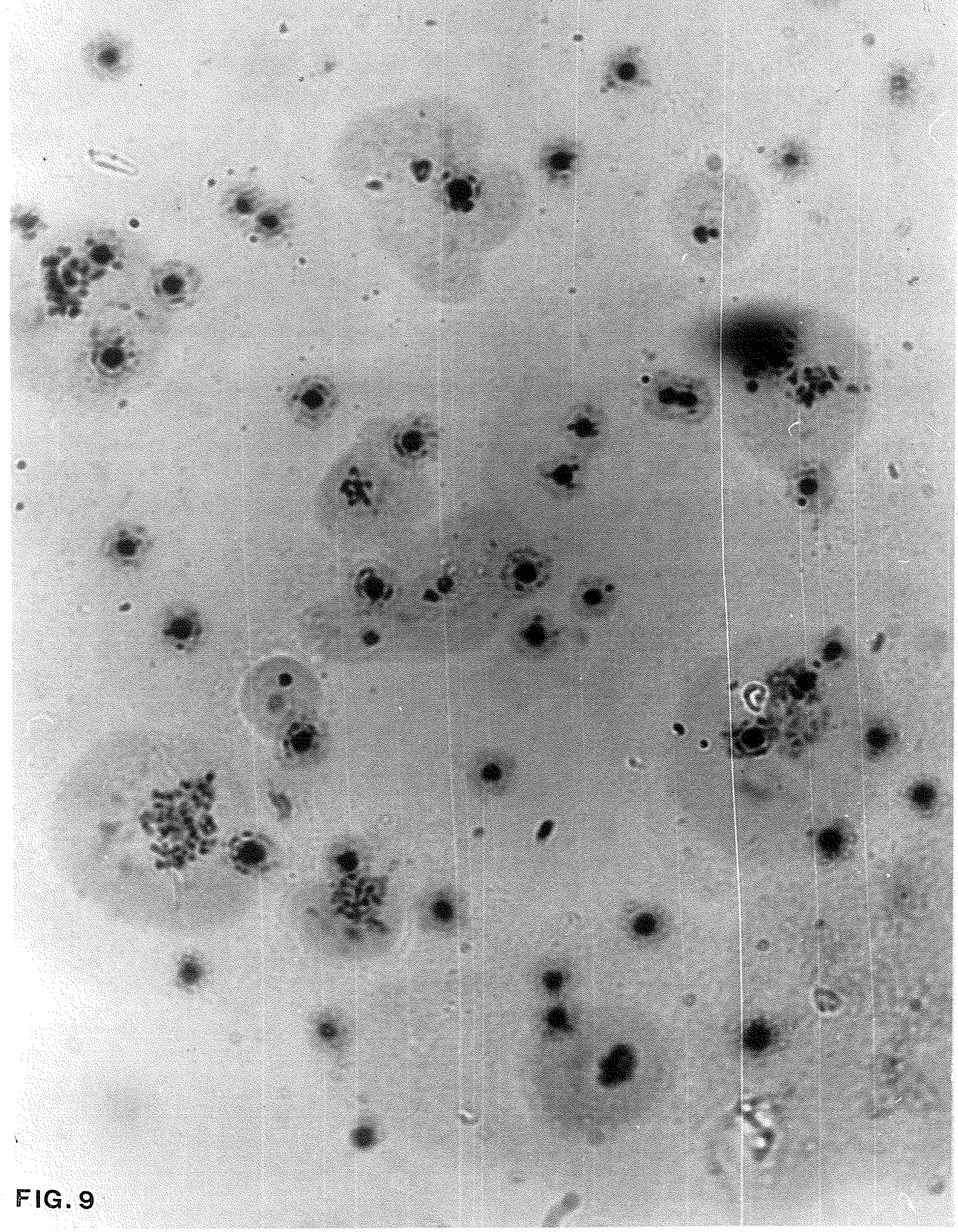


A)

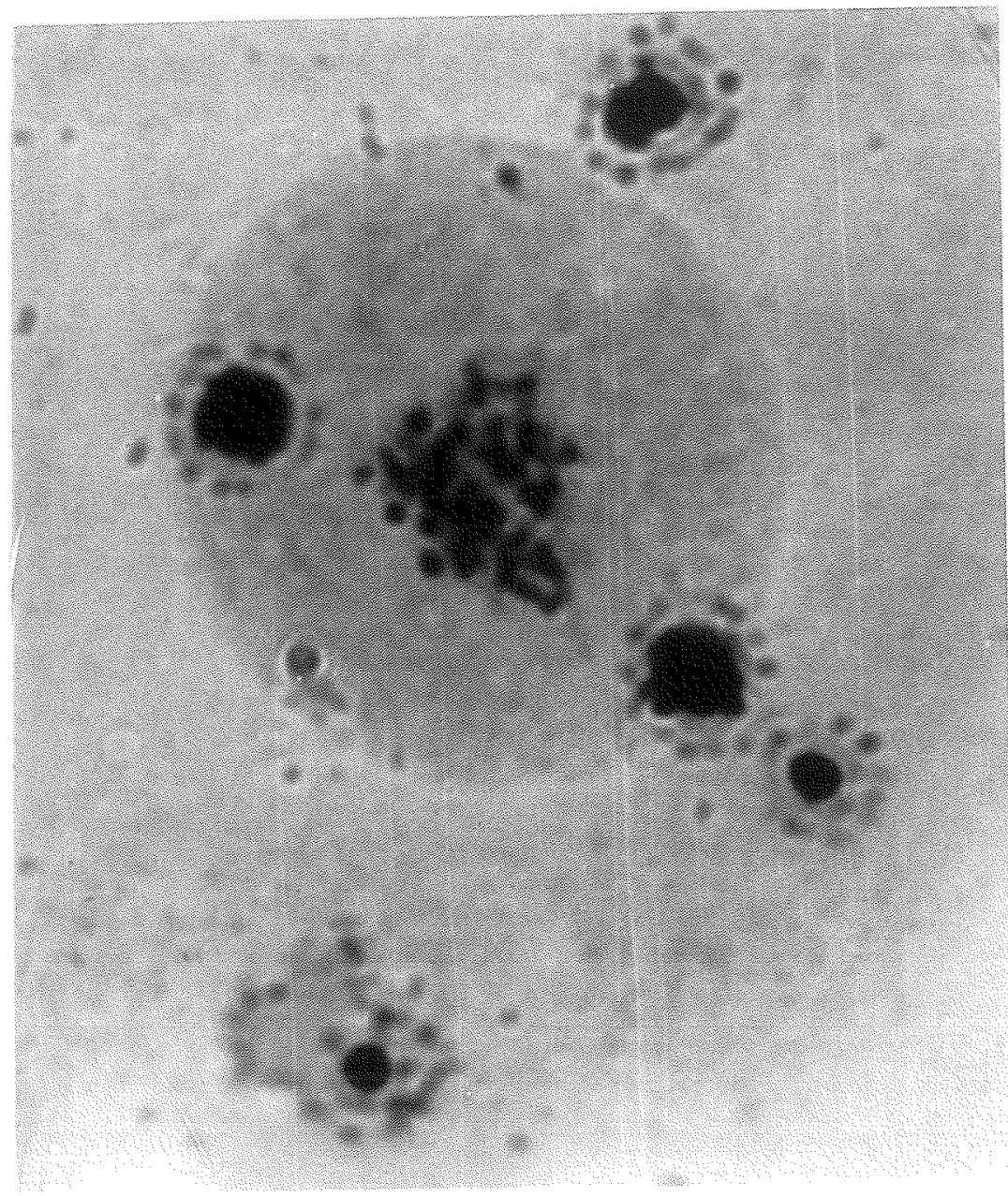

$F / G_{a} 10$

B)

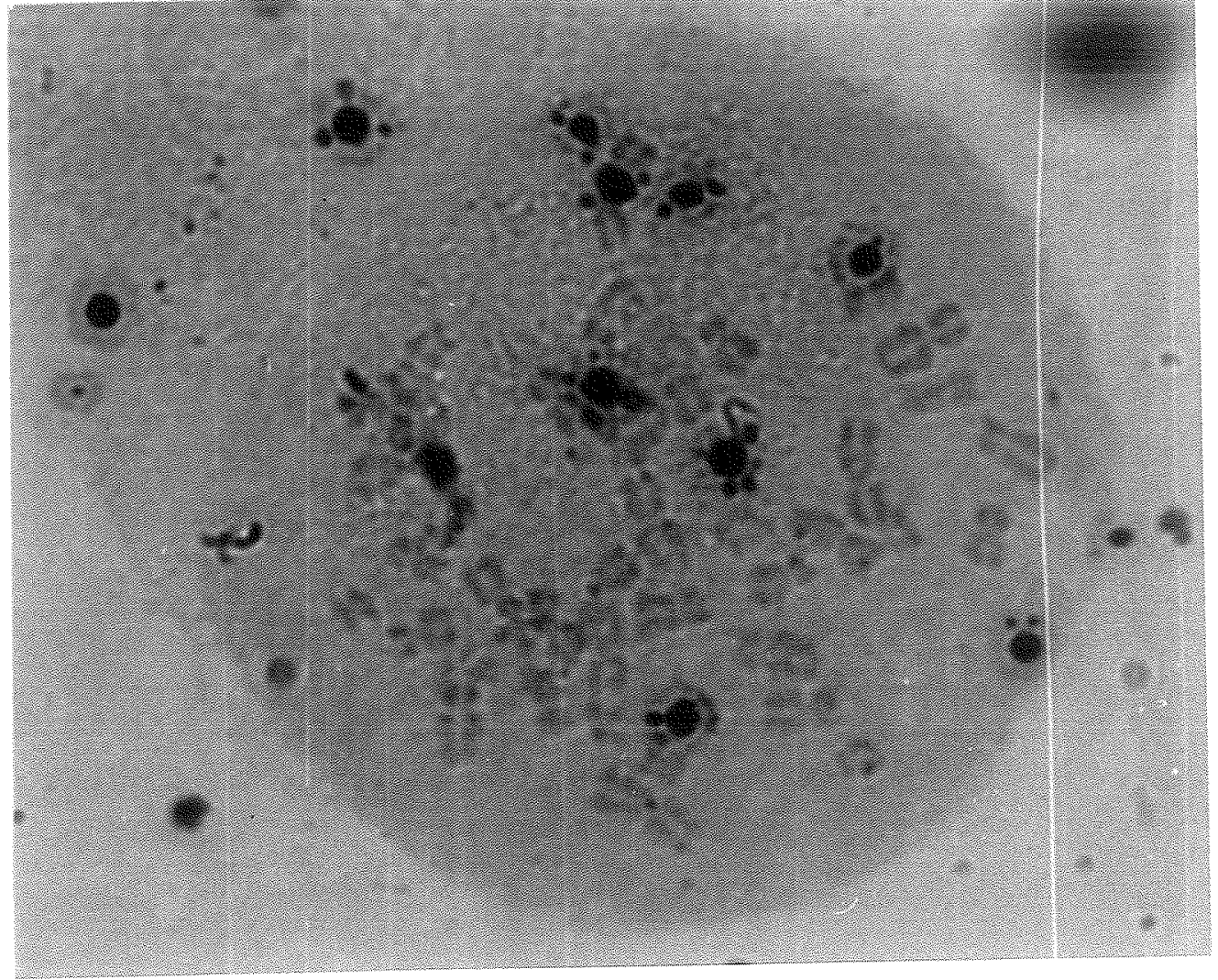


Fig. 11: Histograms showing changes in Iymphocyte a) silver reactivity and b) nuclear diameter after various periods of treatment with 4.0 mM EGTA. All treatments were stimulated with PHA and harvested after 72 hours of culturing. 
$\%$ OF CELLS

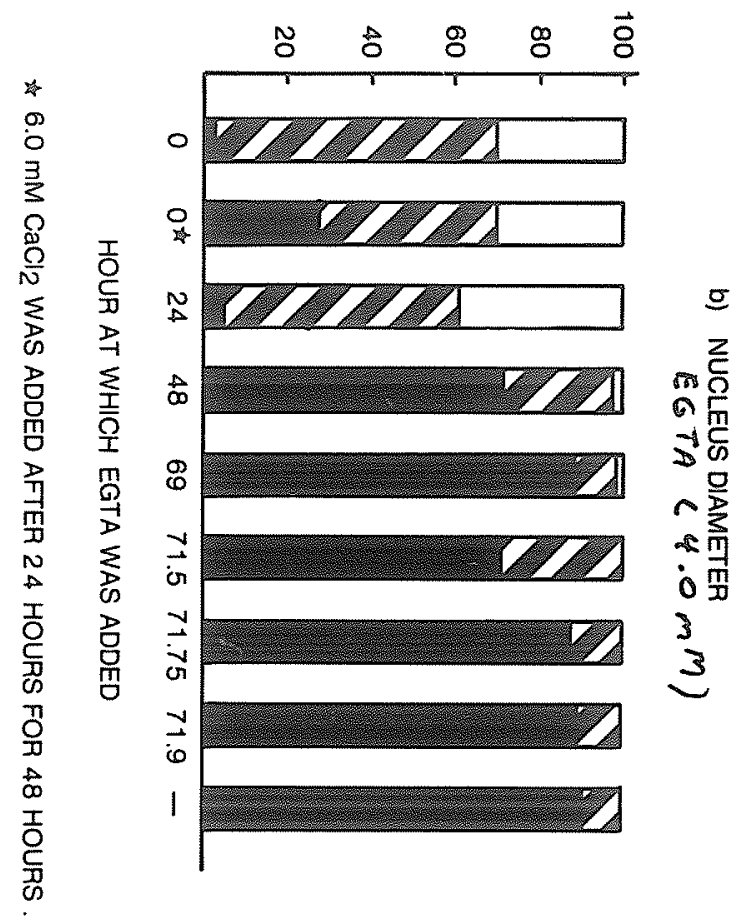

勇贾

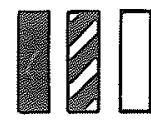

$\%$ OF CELLS

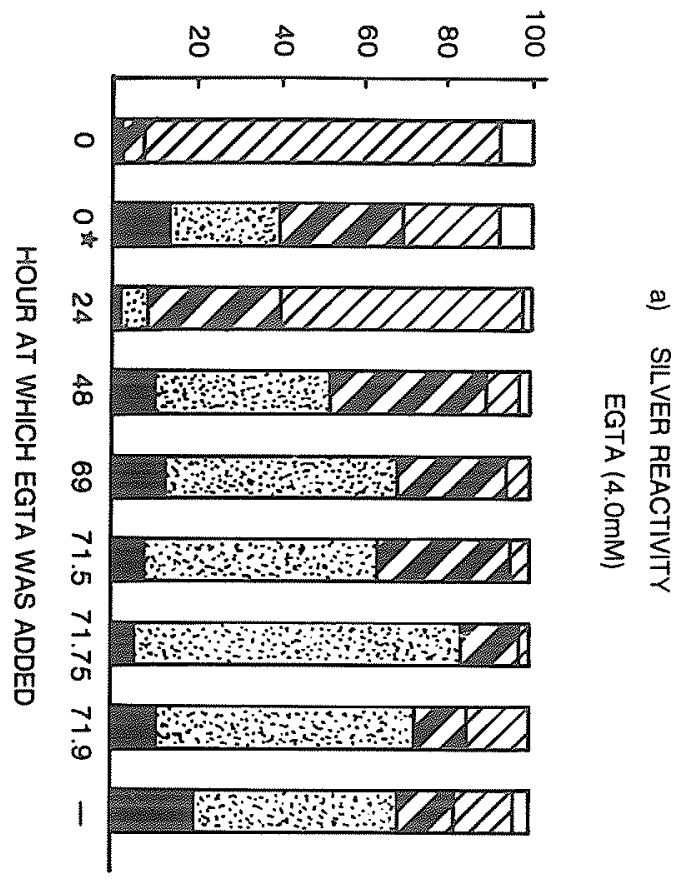

$\frac{\pi}{6}$
$=$

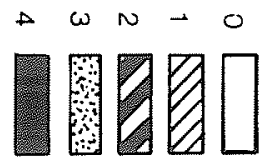


Restoration of $\mathrm{Ca}^{+}$in the form of $\mathrm{CaCl}_{2}$, partially reversed the inhibitory effects of EGTA.

The addition of EGTA $(4.0 \mathrm{mM})$ at the beginning of culturing completely inhibited PHA stimulation of nucleolar silver reactivity (Fig. 12a) and nuclear diameter (Fig. 13a). This inhibition was completely reversed when $\mathrm{Ca}+\mathrm{t}$ was restored to the medium during the first 24 hours of culturing (Figs. 12b and 13b). After this critical period the effects of EGTA could not be reversed by the addition of $\mathrm{CaCl}_{2}$.

Treatment of Iymphocytes with EGTA, prior to the last 24 hours of culturing, prohibited mitosis, and therefore AgNoRs were not observed (Table I).

Greatly increasing extracellular $\mathrm{CaCl}_{2}$, from $1.8 \mathrm{mM}$ to $7.8 \mathrm{mM}$, did not stimulate lymphocyte activity during a 72 hour culture period without PHA (Fig. 14).

The addition of calmodulin to cultured lymphocytes produced some inconsistent results (Figs.15, 16 and 17). Fig. 15 illustrates that the addition of 0.75 and $3.0 \mathrm{mg} / \mathrm{ml}$ calmodulin slightly stimulated nucleolar silver reactivity when compared with untreated, unstimulated controls (Fig. 15a). There was no parallel increase in nuclear diameter (Fig. 15b). Upon repetition, it was found that treatment of lymphocytes with calmodulin $(3.0 \mu \mathrm{g} / \mathrm{ml})$ for varying periods of culturing time, neither stimulated silver reactivity (Fig. 16) nor nuclear 
Fig. 12: Histograms comparing changes in lymphocyte silver reactivity

a) at various times after culturing $\mathrm{PHA}$ stimulated cells in EGTA treated medium. b) after culturing PHA stimulated cells in EGTA treated medium for 72 hours and adding $\mathrm{CaCl}_{2}$ at various intervals.

c) at various times after culturing cells not stimulated with PHA.

d) at various times after culturing cells stimulated with PHA. 
\%OF CELLS

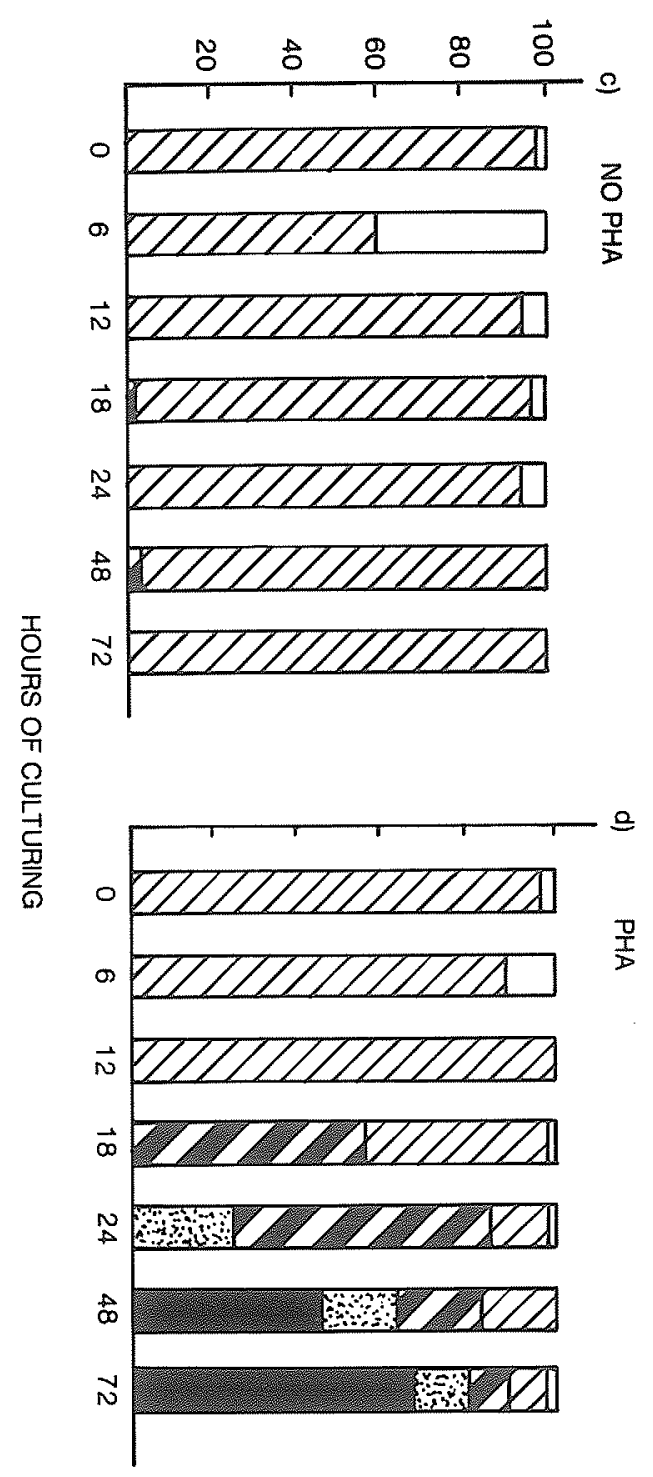

$\%$ OF CELLS

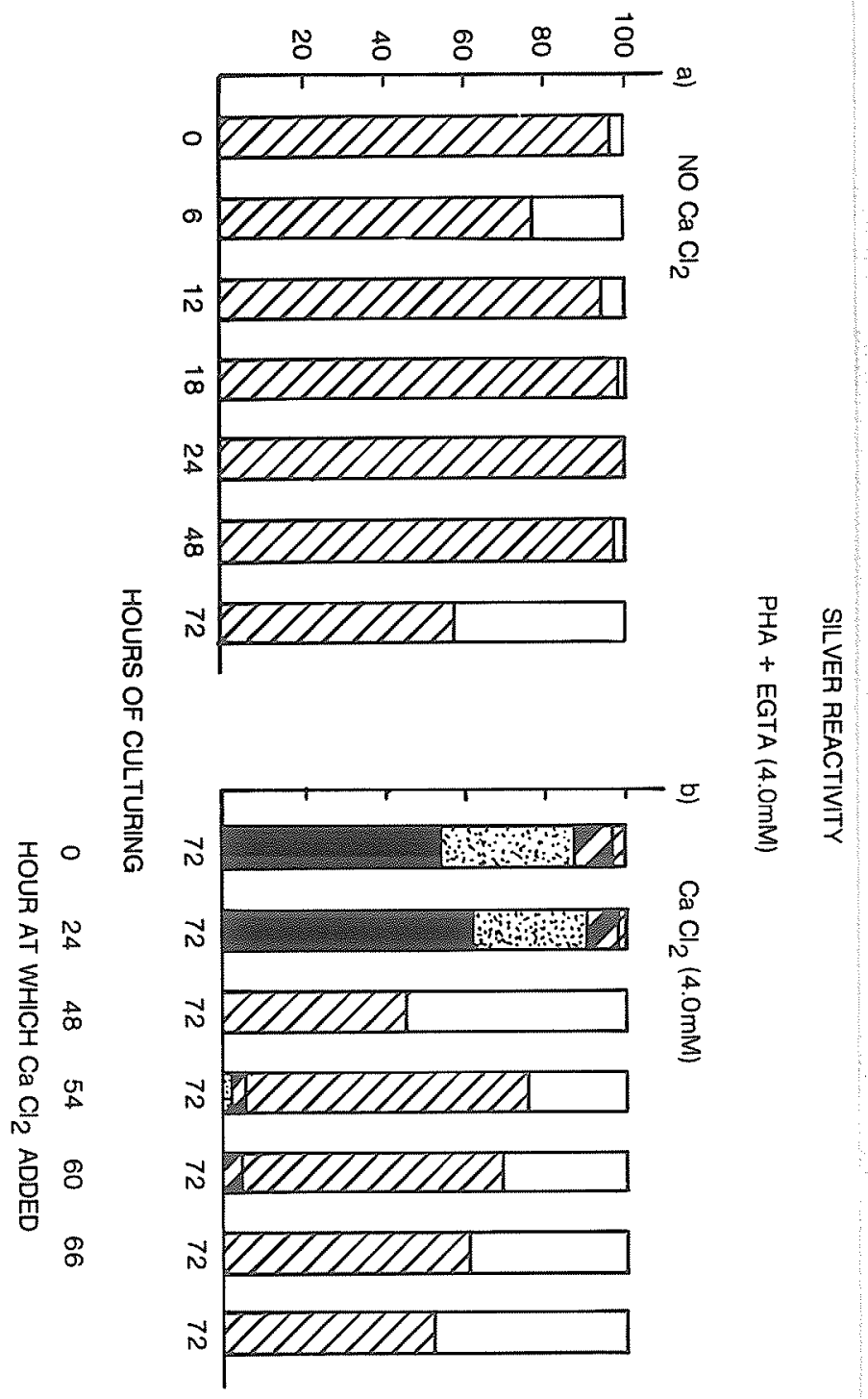

$\triangle \omega N \rightarrow 0$

圈圆圆 
Fig. 13: Histograms comparing changes in lymphocyte nuclear diameter

a) at various times after culturing PHA stimulated cells in EGTA treated medium.

b) after culturing PHA stimulated cells in EGTA treated medium for 72 hours and adding $\mathrm{CaCl}_{2}$ at various intervals.

c) at various times after culturing cells not stimulated with PHA. 

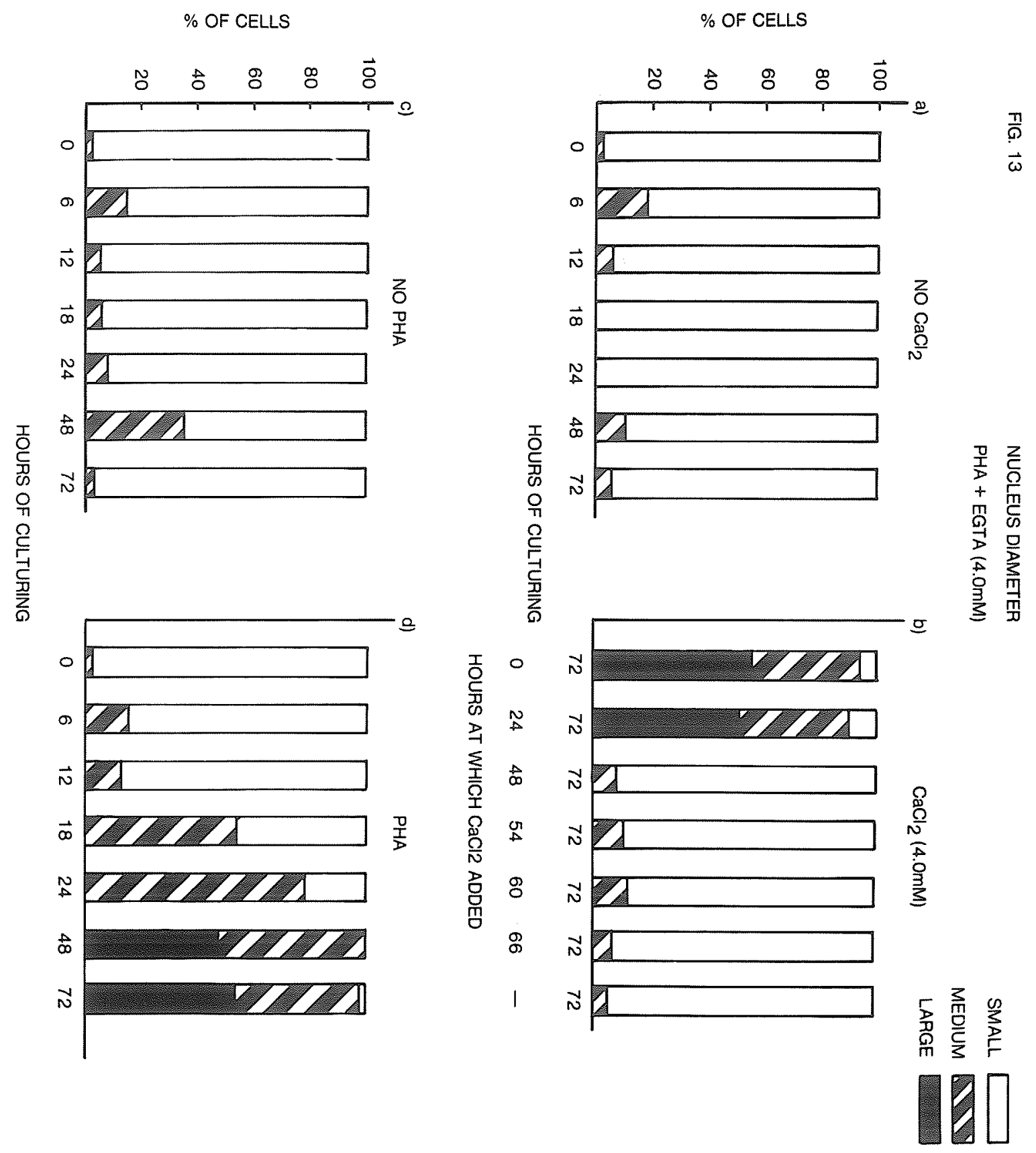
Fig. 14: Histograms showing lymphocyte silver reactivity and nuclear diameter with and without adding extra $\mathrm{CaCl}_{2}$ to the culture medium. Untreated McCoy's medium contained $1.8 \mathrm{mM} \mathrm{CaCl}_{2}$ and treated medium $7.8 \mathrm{mM} \mathrm{CaCl} 2$. PHA was not added to the cultures. Cells were harvested after 72 hours of culturing. 
FIG. 14

SILVER REACTIVITY

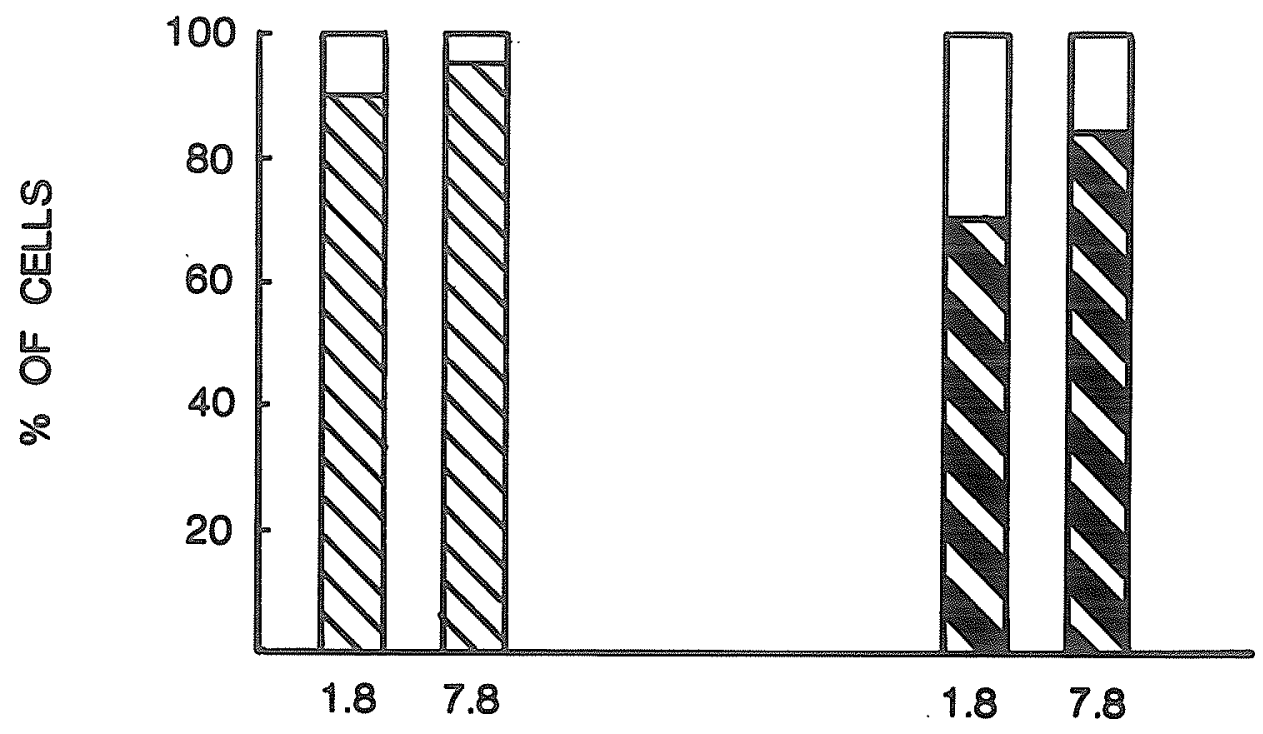

$\mathrm{Ca} \mathrm{Cl} 2(\mathrm{mM})$
NUCLEUS DIAMETER

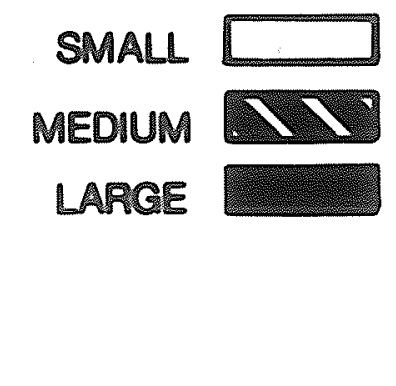

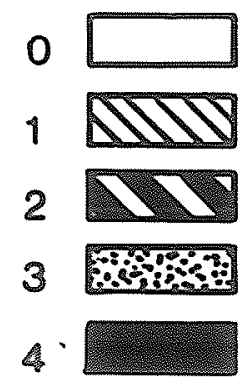


Fig. 15: Histograms showing lymphocyte

a) silver reactivity and b) nuclear diameter after culturing cells for various periods of time with and without calmodulin. 
$\%$ OF CELLS

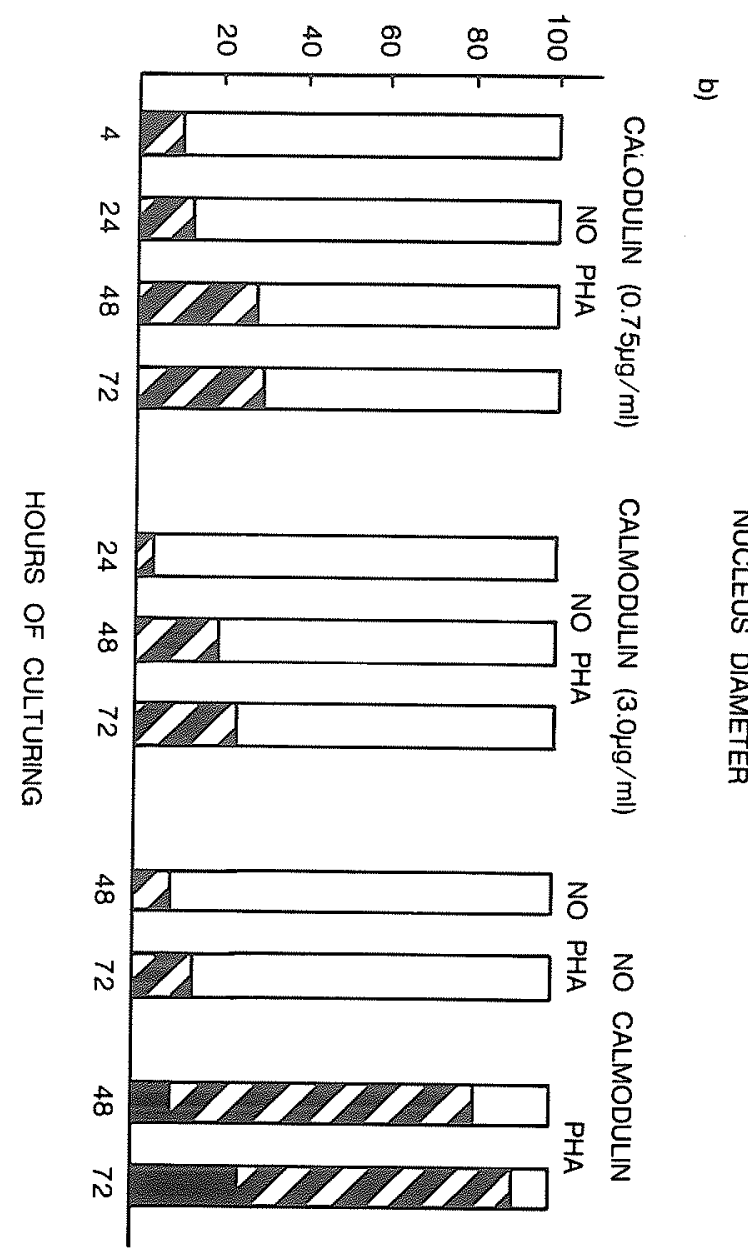

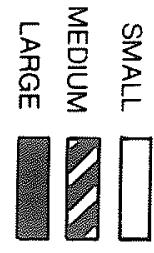

$\%$ OF CELLS

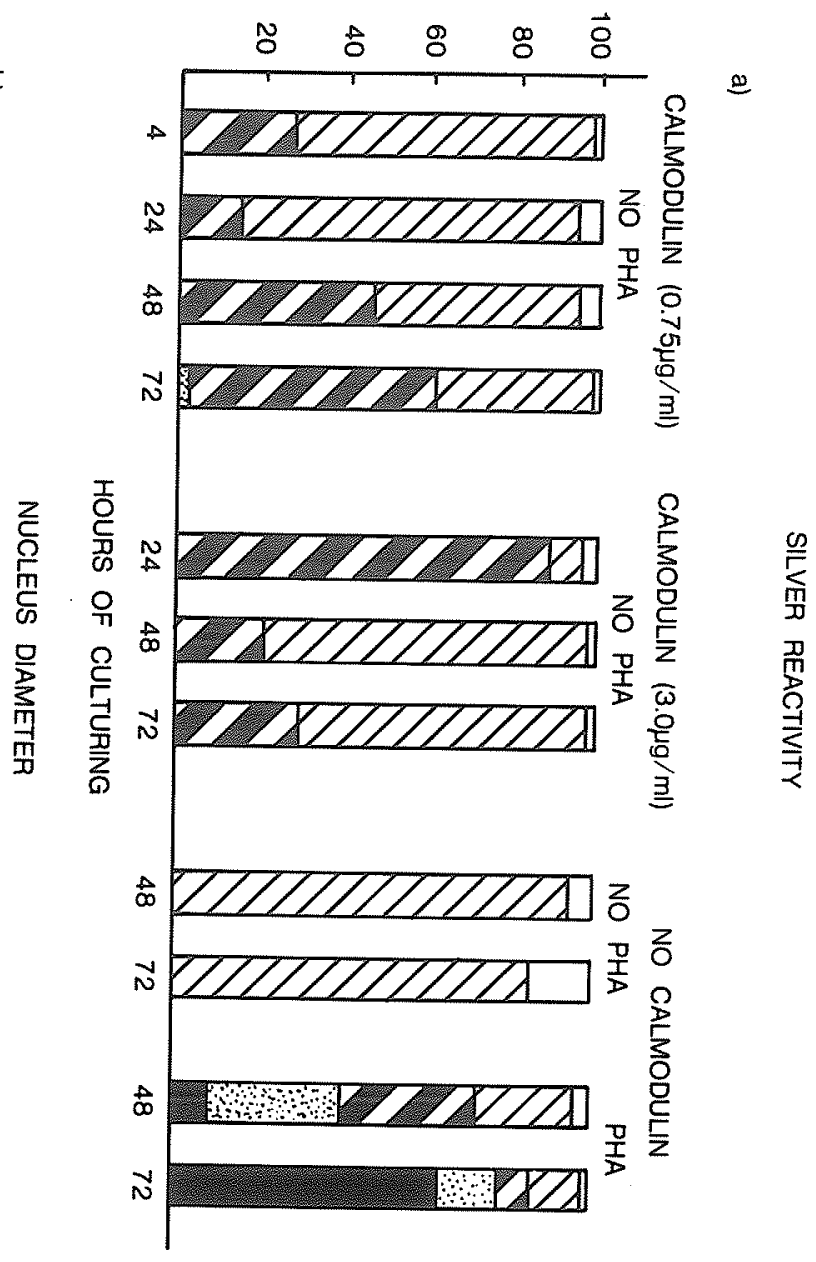

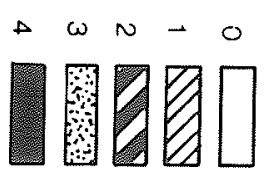


Fig. 16: Histograms showing lymphocyte silver reactivity after culturing cells for various periods of time with and without calmodulin. 
\% OF CELLS

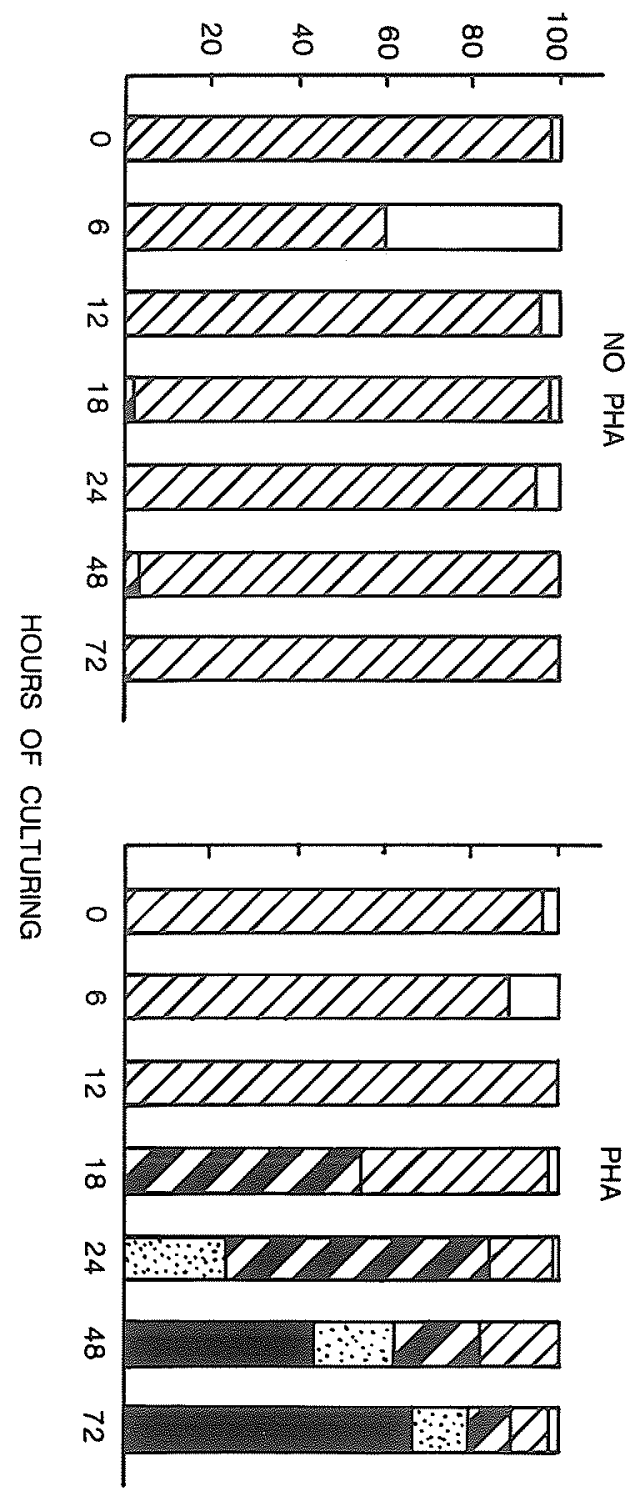

$\%$ OF CELLS

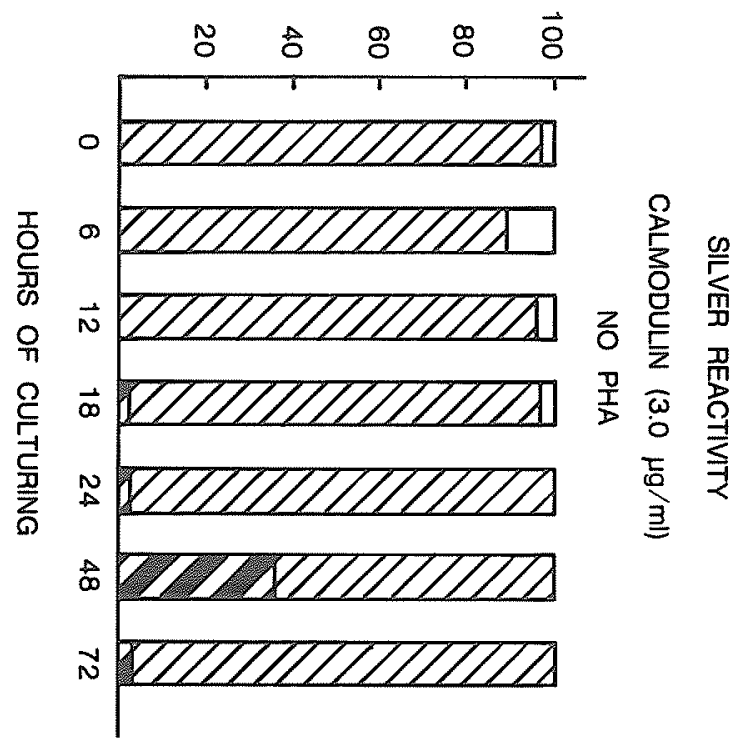

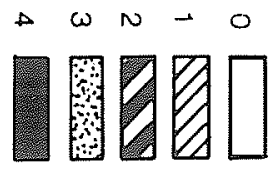


diameter (Fig. 17). Further experiments were prohibited by the limited quantity of calmodulin. 
Fig. 17: Histograms showing lymphocyte nuclear diameter after culturing cells for various periods of time with and without calmodulin. 
$\%$ OF CELLS
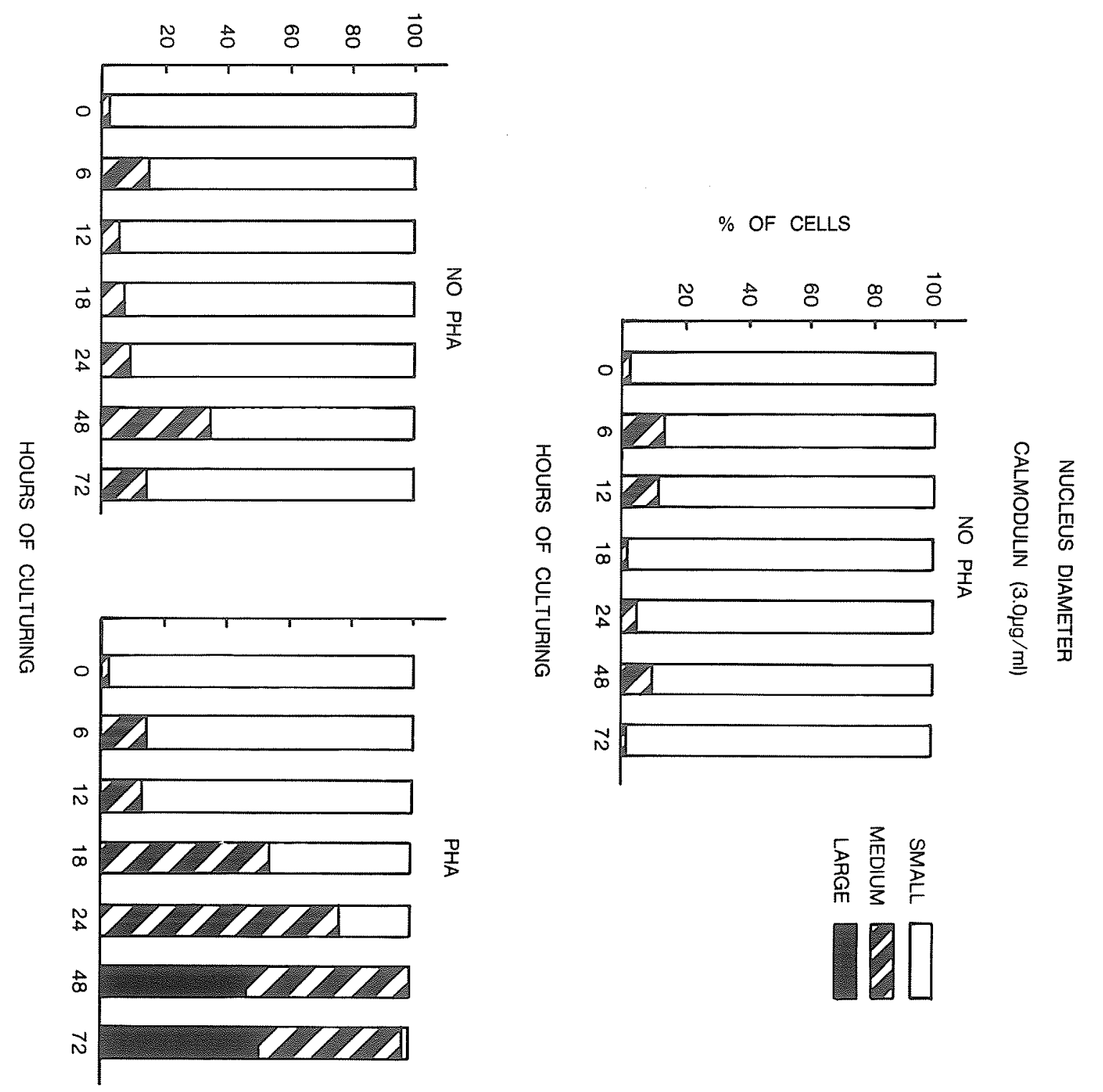
DISCUSSION

\section{PARAMETERS OF LYMPHOCYTE ACTIVATION}

Quantification of data was difficult. The silver nitrate method could not be completely standardized. Even within limited areas of a preparation, there were differences in intensity of the silver reaction. Metallic silver granules were deposited randomly over treated slides. Over treatment led to non-specific reactions, first within the nucleus and later over the entire slide.

Despite these problems, the size of the reactive area is a good indication of rRNA synthesis. There was almost precise $(0.96$ and 0.99 ) correlation between the ratio of silver reactive area to nucleus area and the rate of uridine incorporation (Hofgärtner et al., 1979). This correlation was quantified by cytophotometrically measuring the silver reactive area and total nuclear area, during preferential inhibition of rRNA with Actinomycin D. There was also good correlation between nuclear area and the area of silver reactivity, but not between nuclear area and the number of silver reactive areas (Hofgärtner et al., 1979).

In this study, silver reactivity was Iinearly related to the log of the nuclear diameter (Fig. 6). As silver reactivity increased, nuclear diameter tended to increase by 10-fold, indicating that the ratio of silver reactivity to nuclear diameter decreased in larger cells. Since the determination of silver reactivity was 
subjectively evaluated and not based on accurate measurement of the silver reactive area, the apparent decrease in ratio is likely an artifact of subjectively categorizing silver reactivity into a limited number of categories. The important point to be noted is the correlation between silver reactivity, as measured in this experiment and nuclear diameter. 


\section{TRANSFORMATION}

Unstimulated cultured lymphocytes were characterized by a small nuclear diameter and a small silver reactive area, neither of which increased with time (Figs. $3 \& 5$ ). After PHA stimulation, lymphocytes reenter the cell cycle, enlarge and the amount of silver reactivity increased (Figs. $4 \& 5$ ). This is comparible to the findings of Schwarzacher et al., (1978) and Arrighi et al. (1980). Schwarzacher et al. (1978) reported sma11, non-activated lymphocytes, in cultures 48 hours post PHA stimulation. These lymphocytes did not have silver reactive nucleoli. In this study, small non-activated lymphocytes were observed even 72 hours post PHA stimulation, but most had a small, distinct silver reactive area. Even unstimulated, uncultured peripheral Iymphocytes (as represented by 0 hours of culturing, Fig. 5) nearly always had distinct silver reactive areas (Fig. 3).

Transformation with PHA did not induce uniform changes in the lymphocyte population. After stimulation, variability in lymphocyte size and silver reactivity was observed, even within one culture. This must reflect a difference in the rate of response and/or intensity of response to the same stimulus. Several environmental factors influence in vitro transformation. For example, the number of cells, duration and surface area of cultures, $\mathrm{pH}$ and the concentration of 
stimulant affect transformation (Alford, 1970). Presumably these factors are relatively constant within a single culture, and yet great heterogeneity exists.

Morimoto and Wolff (1980) attributed this heterogeneity to variability in the times at which lymphocytes began to synthesis DNA (S-phase) in response to PHA. Cells have about the same generation time after entering their first S-phase. In a 64 hour PHA stimulated culture, $10 \%$ of the metaphases were in their first division, $40 \%$ in their second and $50 \%$ in their third. The first generation metaphase began DNA synthesis after 40 hours, while most of the third generation metaphases began at 24 to 32 hours. As silver reactivity and nucleus size are dependent on the cell cycle, all hetergeneity observed may be dependent on the variation in rate of response to $\mathrm{PHA}$.

This does not eliminate the possibility that lymphocytes within a given population, also vary in how they respond. Purtell and Anthony (1975) found guinea pig lymphocytes had at least two rRNA maturation pathways, only one of which was stimulated by PHA. This indicates either all lymphocytes have the potential for both pathways, or that there are subpopulations of cells which may be differentiated by their response to PHA.

The peak period of increase of silver reactivity and nuclear diameter was 18 to 48 hours after the addition of PHA (Fig. 5). 
This is similar to the findings of Arrighi et al. (1980) and is correlated with the period of increased rRNA and DNA synthesis. Lymphocyte rRNA synthesis peaks at about 18 hours (Purtell and Anthony, 1975) to 20 hours (Cooper, 1972) post PHA. DNA synthesis begins at 24 to 32 hours post stimulation with nearly 90\% of cells having entered S-phase before 40 hours (Morimoto and Wolff, 1980). 
III. DECREASING EXTRACELLULAR POTASSIUM

Decreasing extracellular $\mathrm{K}^{+}$from normal levels $(5.0 \mathrm{mM})$ to $14 \%$ of normal $(0.7 \mathrm{mM})$ did not affect the silver reactivity or nuclear diameter of PHA treated lymphocytes (Fig. 7), nor did it affect the number of AgNoRs in metaphase cells (Table 1). A mean of 8.0 AgNORs/cell was observed in cells cultured in medium containing $0.7 \mathrm{mM} \mathrm{K}$. This is comparable with the results of Ray and Pearson (1979) who reported a mean of 7.7 , and Goodpasture et al. (1976) who reported a mean of 8.1 .

External concentrations of $\mathrm{K}^{+}$are in dynamic equilibrium with internal levels. As external $\mathrm{K}^{+}$rises from zero, internal $\mathrm{K}^{+}$levels of human Iymphocytes rise steeply in a sigmoidal fashion (Negendank and Shaller, 1979). At 5mM external $\mathrm{K}^{+}$, internal $\mathrm{K}^{+}$is saturated at about $129 \mathrm{mM}$. At $0.7 \mathrm{mM}$ external $\mathrm{K}^{+}$, internal $\mathrm{K}^{+}$is approximately $85 \mathrm{mM}$. Thus the $86 \%$ reduction in extracellular $\mathrm{K}^{+}$in this experiment, resulted in only an approximate $34 \%$ decrease in intracellular $\mathrm{k}^{+}$. Ledbetter and Lubin (1977) found that when intracellular $\mathrm{K}^{+}$ levels of human fibroblasts fell below 60 to $80 \%$ of control levels, protein synthesis decreased in proportion to further reduction of $\mathrm{K}^{+}$. Low cellular $\mathrm{K}^{+}$limits the transfer of amino acids from aminoacyl soluable RNA to the polypeptide during protein synthesis (Lubin and Ennis, 1964). The degree of $\mathrm{K}^{+}$reduction required to 
inhibit growth or protein synthesis varies with the cell type. Pollack and Fisher (1976) decreased extracellular $\mathrm{K}^{+}$of mammalian cell lines from $6 \mathrm{mM}$ to $0 \mathrm{mM}$. Less than $2 \mathrm{mM} \mathrm{K} \mathrm{K}^{+}$reduced protein synthesis without affecting RNA synthesis. Cell division occured at $1.2 \mathrm{mM} \mathrm{K}{ }^{+}$. According to Negendank and Shaller (1979), $2 \mathrm{mM}$ external $\mathrm{K}^{+}$resulted in near saturation of internal lymphocyte $\mathrm{K}^{\dagger}$ and thus the protein inhibition observed by Pollock and Fisher (1976) would not be expected. This incongruity may be explained by cellular differences in response to extracellular $\mathrm{K}^{+}$. Fluctuations as great as those tested in this experiment are not known to occur in vivo. $K^{+}$influx doubles within minutes after PHA addition (Quastel and Kaplan, 1970b), but cellular $\mathrm{K}^{+}$concentrations remain constant due to an increased efflux of the ions (Hamilton and Kaplan, 1977). The approximate $34 \%$ decrease in cellular $\mathrm{K}^{+}$in this experiment was not sufficient to limit cell growth or division. Potassium is universally required by all cells, but it is unlikely that it is important in regulation of rRNA synthesis. 
IV. DECREASING EXTRACELLULAR MAGNESIUM

Decreasing extracellular $\mathrm{Mg}^{H+}$ from normal levels (1.0 mM) to $14 \%$ of normal $(0.14 \mathrm{mM})$ did not affect the silver reactivity or nuclear diameter of PHA treated lymphocytes (Fig. 7), nor did it affect the number of AgNORs in metaphase cells (Table 1). The mean of $7.6 \mathrm{AgNORs/cell} \mathrm{observed} \mathrm{in} \mathrm{cells} \mathrm{cultured} \mathrm{in} \mathrm{Mg}+$ reduced medium (Table 1) is comparable to the results of Ray and Pearson (1979) who reported a mean of 7.7 , and Goodpasture et a1. (1976) who reported a mean of 8.1 .

As intracellular and extracellular $\mathrm{Mg}^{++}$remains relatively constant at about $1 \mathrm{mM}$ (Bygrave, 1978b), further reduction of $\mathrm{Mg}^{++}$ level (below $0.14 \mathrm{mM}$ ), should not be necessary to demonstrate any physiologically feasible regulatory role that $\mathrm{Mg}+\mathrm{t}$ might have. The lack of hormones and other mechanisms controlling $\mathrm{Mg}^{++}$levels, further emphasizes the unlikelihood that $\mathrm{Mg}^{++}$is important in the regulation of gene activity. 


\section{CALCIUM}

\section{A. Decreasing extracellular $\mathrm{Ca}+\mathrm{H}$}

Chelation of extracellular CaH with EGTA early during activation, completely inhibited the increases in silver reactivity and nuclear diameter associated with PHA stimulation (Figs. 11, 12a, \& 13a). EGTA could be added as late as 24 hours post PHA with resultant inhibition. This study confirms those of Alford (1970) and Whitney and Sutherland (1972) who found Catt to be essential for mitogenetic effects of PHA.

The inhibitory effects of EGTA were totally reversible if $\mathrm{CaCl}_{2}$ was added to the medium within 24 hours of PHA stimulation (Figs. 12b \& 13b). By 48 hours the effects were irreversible. Alford (1970) and Whitney and Sutherland (1972) also found the inhibitory effects to be reversible.

A slight decline in silver reactivity and nuclear diameter was observed when $\mathrm{Ca}^{+}+$was chelated during the last 24 hours of a 72 hour culture period with high concentrations of EGTA (Fig. 8). Since partial restoration of $\mathrm{Ca}+$ partially reversed the inhibitory effects, this was not a toxic effect of EGTA. Possibly the reduced $\mathrm{Ca}^{+}+$levels inhibited stimulation of Iymphocytes which were late to enter their first metaphase.

A mean of 7.5 AgNoRs per cell occurred in cells treated with 
$1.8 \mathrm{mM}$ EGTA for the last 24 hours of culturing (Table 1). This was comparable with control values and with values reported by Goodpasture et a1. (1976). As this treatment also did not affect nucleolar silver reactivity and nuclear diameter, it is not surprising that the number of AgNORs was not affected. Longer treatment periods with EGTA prohibited mitosis and therefore NORs were not observed. Whitney and Sutherland (1972) found that inhibition of DNA synthesis was not possible if EGTA was added later than 12 hours post PHA. As S-phase begins at about 24 hours post PHA, these authors concluded that EGTA does not directly inhibit DNA synthesis. The present study showed EGTA inhibits lymphocyte activation if it was added as late as 24 hours post PHA. This coincides with the beginning of S-phase.

If $\mathrm{Ca}^{+}$t had a direct effect on DNA or RNA synthesis, its removal prior to these events would result in inhibition of growth. As the 1ymphocyte cell cycle was found to be constant at 16 to 18 hours (Morimoto and Wolff, 1980), all cycling cells in a 72 hour culture would have entered their last S-phase at 52 to 54 hours. The addition of EGTA, 4 to 6 hours prior to this last S-phase did not inhibit lymphocyte stimulation. Once the cells have been stimulated to enter the dividing population, they are insensitive to EGTA. Sufficient PHA to stimulate a full response binds to the lymphocyte membrane within minutes in an irreversible manner 
(Whitney and Sutherland, 1972). As inhibition can occur as late as 24 hours post PHA, the essential need for $\mathrm{Ca}^{++}$must not only be involved in the binding of PHA to the cell membrane. Within minutes after the addition of PHA a surge of $\mathrm{Ca}^{++}$ moves into the cells. Whitfield et al. (1979) discounted this surge as being the stimulating factor for the following two reasons: (i) Firstly, studies of Rosentreich and BIumenthal (1977) and Gemsa et al. (1979) showed that Ionophore A23187 did not produce a $\mathrm{Ca}^{+}$influx surge and yet did stimulate DNA synthesis. According to Claret-Berthon et al. (1977), this ionophore initiates a surge of calcium ions and "non-exchangeable" calcium salts from the mitochondria. Mobilization of $\mathrm{Ca}+\mathrm{t}$ from intracellular reservoirs may have the same effect as the CaH influx surge.

(ii) Secondly, if the surge initiates DNA synthesis, then adding EGTA after the surge should not have any effect on DNA synthesis. The addition of EGTA as late as 24 hours post PHA is still able to inhibit DNA synthesis. This does not prove that the surge is not essential for transformations. It does demonstrate that the active role of $\mathrm{Ca}^{+}$in transformation is not finished immediately after the surge.

The CaHt surge results in a cellular cAMP surge. Within 1 to 2 minutes post PHA, up to a $300 \%$ increase in cAMP occurred, which returned to control levels by 6 hours (Smith et al., 1971). High concentrations of exogenous cAMP can stimulate lymphoblast 
Fig. 18: Possible explanation of the role of $\mathrm{Ca}^{++}$in $\mathrm{PHA}$ stimulation of lymphocytes. PHA stimulates a $\mathrm{Ca}^{++}$ influx surge. This activates calmodulin (CDR) to bind with adenylate cyclase and stimulate an increase in production of endogenous CAMP. CAMP binds to and activates various protein kinases, some of which are membrane bound and may also be dependent upon calmodulin for activation. Activated kinases stimulate transformation via a phosphorylated product.

Based upon this model the possible mechanisms of EGTA. action are (the numbers below correspond with the numbered locations on the diagram):

1) EGTA chelates extracellular $\mathrm{Ca}^{++}$preventing the post PHA Ca+t influx surge and thus stimulation of rRNA and DNA synthesis.

2) EGTA chelates membrane associated $\mathrm{Ca}^{++}$, inhibiting enzyme reactions leading to stimulation of rRNA and DNA synthesis.

3) If the cell membrane is disturbed allowing EGTA to enter the cell, intracellular $\mathrm{Ca}^{+}+$would be chelated and $\mathrm{Ca}^{+}+$dependent enzyme reactions inhibited. Nucleolar rRNA synthesis may be regulated by a $\mathrm{Ca}^{++}$dependent enzyme(s). 


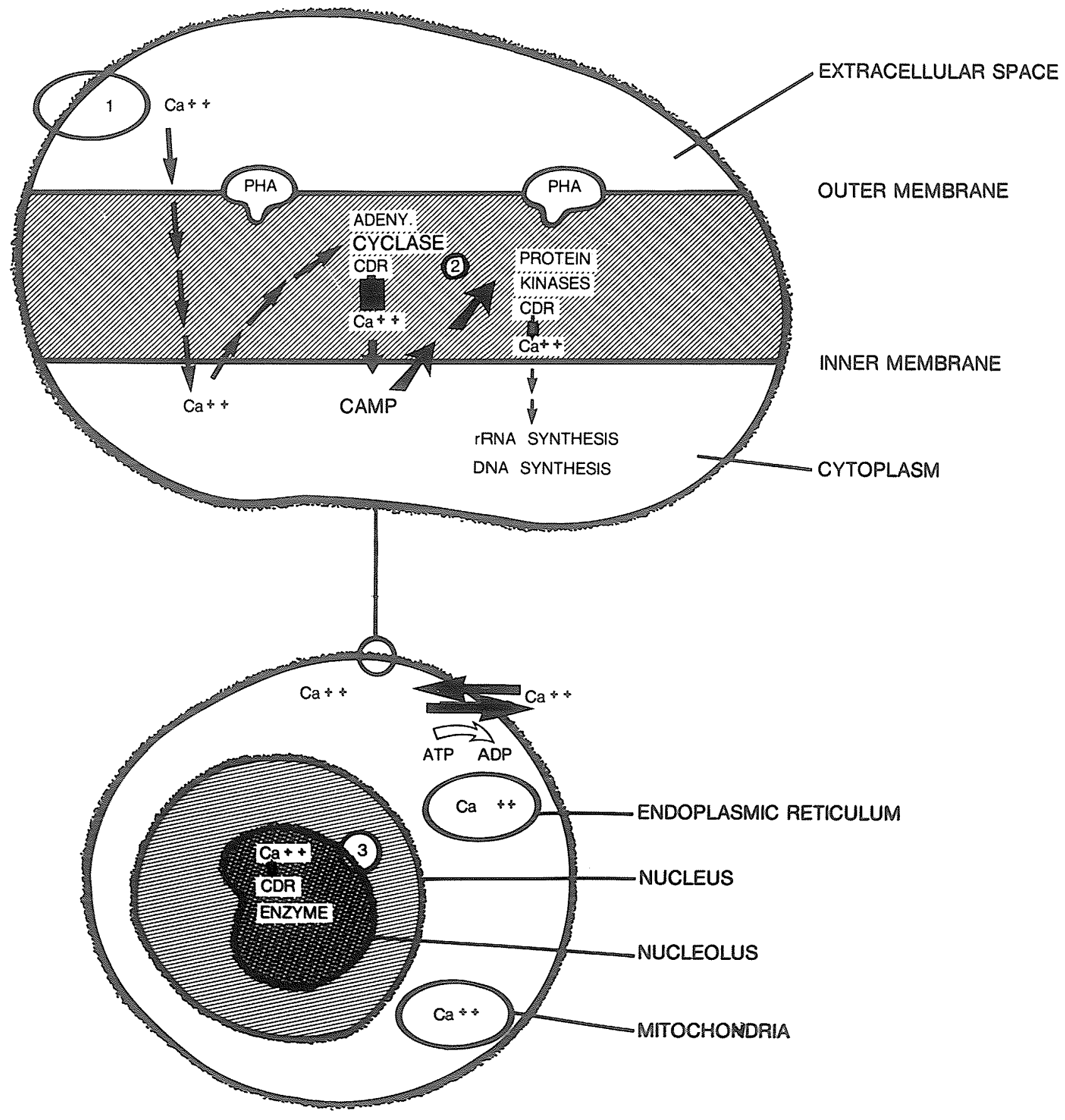

FIG. 18 
proliferation (Whitfield et al., 1972).

EGTA displaces approximately $63 \%$ of total exchangeable $\mathrm{Ca}^{++}$ (Claret-Berthon et a1., 1977). It does not penetrate the cell membrane, totally chelates the 1st compartment of rapidly exchangeable Cat+ ( 4 min.), and chelates $85 \%$ of the 3 rd compartment of slowly exchangeable cat+ (223 min.). This 3rd compartment is presumed to be $\mathrm{Ca}+\mathrm{H}$ in more intimate contact with the membrane. EGTA may inhibit lymphocyte transformation by chelating $\mathrm{Ca}^{++}$ bound to calmodulin associated with membrane bound adenylate cyclase and protein kinases (Fig, 18). The Cat+ surge activates calmodulin which binds with adenylate cyclase. Adenylate cyclase, when activated by calmodulin increases endogenous levels of cAMP. cAMP binds to and activates various protein kinases, some of which are membrane bound and may be also dependent upon calmodulin for activation. Whitfield et al. (1980) proposed that these activated kinases may stimulate transformation via a phosphorylated product. According to this model the initial Ca+t surge is critical because it stimulates adenylate cyclase which in turn stimulates a chain of events leading to activation of proliferation genes. Ca+t, through its association with calmodulin, is also essential for one or more of the critical events leading to transformation. Therefore the addition of EGTA after the Ca+t surge would also inhibit transformation.

This hypothesis could be tested by adding lanthanum to PHA stimulated lymphocytes after the initial Ca+t surge. Lanthanum 
specifically displaces the 1st compartment of rapidly exchangeable calcium, without disturbing other external pools (Claret-Berthon et al. 1977). Since it does not displace Catt which is in more intimate contact with the membrane, it would not be expected to inhibit transformation.

\section{B. Increasing extracellular $\mathrm{Ca}+4$}

Increasing extracellular $\mathrm{CaCl}_{2}$ from $1.8 \mathrm{mM}$ to $7.8 \mathrm{mM}$ did not stimulate lymphocyte activity during a 72 hour culture period without PHA (Fig. 14). Anghileri and Heidbreder (1978) found that increasing extracellular $\mathrm{Ca}{ }^{+}$to 10 to $50 \mathrm{mM}$ stimulated DNA, RNA, and protein synthesis in liver cells. Yang and Morton (1971) found $\mathrm{Ca}^{++}$and $\mathrm{Mg}^{+}$stimulated mitotic activity and DNA synthesis in cells of various differentiated systems. Whitfield et al. (1969b) found that increasing $\mathrm{Ca}^{+}$to $1.2 \mathrm{mM}$ stimulated mitotic activity of rat thymocytes. Whitfield et al. (1979) found that suddenly raising extracellular $\mathrm{Ca}^{+}$of fetal mouse cells from $1.8 \mathrm{mM}$ to $5.0 \mathrm{mM}$, stimulated 20 to $60 \%$ of cells to resume cycling and initiate DNA synthesis. The authors considered this a meaningless artifact of a physiologically improbable $\mathrm{Ca}+$ shock.

Rapidly responding thymic Iymphocytes, which includes 10-15\% of the thymic population, are proliferatively activated but require exogenous stimulation to initiate DNA synthesis (Whitfield et al. 1980). Raising extracellular Ca+ from $1.0 \mathrm{mM}$ to $1.5 \mathrm{mM}$ directly 
initiated DNA synthesis. Circulating peripheral lymphocytes are not proliferatively activated and cannot be activated by increasing exogenous $\mathrm{Ca}^{+}$alone. Additional membrane stimulation is required.

C. Increasing exogenous calmodulin

The addition of exogenous calmodulin did not significantly activate the proliferative genes of 1ymphocytes (Figs. 15, 16, \& 17). A slight increase in nucleolar silver reactivity was observed in comparison to untreated, unstimulated controls (Fig. 15a), but this was not sufficient to induce mitosis. As synthesis of the protein would inhibit the speed of response to stimulation, it is unlikely that the quantity of calmodulin would be a rare limiting factor in regulating rRNA and DNA synthesis. It is more likely that an excess of calmodulin is activated by $\mathrm{Ca}^{++}$surges to stimulate transformation. 
VI. SIGNIFICANCE OF SILVER NITRATE REACTIVITY

Histochemical studies on the nature of silver reactivity have demonstrated that interactions of silver ions with the carboxyl group of acidic proteins, involved in rRNA transcription, are primarily responsible for the reaction (olert et al., 1979). Esterification of carboxyl groups inhibits the reaction. Reactive protein is located in the fibrillar region of the nucleolus, not in the granular region. Thus it is not part of the RNP complex (Hubbel1 et al., 1979), but it is strongly correlated with rRNA synthesis (Hofgärtner, 1979).

Harper et al. (1980) reported labelling of the nucleus of rat liver and adrenal cortex cells with antibody for calmodulin in a pattern consistent with nucleolar organization. The amount of labelling increased with hormonal activity. Thus it appears that calmodulin localizes in the nucleolus, in response to appropriate stimulation.

Calmodulin is characterized by thermal stability and abundant acidic amino acids which furnish carboxylate groups for the reversible binding of $\mathrm{Ca}^{++}$(Cheung, 1980). These characteristics match with the requirements for the silver reactive protein. The silver nitrate reaction was stable at temperatures in the range of 60-70 ${ }^{0} \mathrm{C}$ (personal observations). The carboxylate groups provide binding sites for silver ions. 
Most regulatory roles previously attributed to calcium ions, require its association with calmodulin (Means and Dedman, 1980). When calmodulin binds Ca ${ }^{+}$it becomes an active more helical molecule (Liu and Cheung, 1976; Dedman et al., 1977), which binds to an apoenzyme to form a holoenzyme. Such a holoenzyme may govern the rate of rRNA synthesis and be responsible for reducing colourless silver nitrate to black metallic silver. 
VII. SIGNIFICANCE OF $\mathrm{Ca}^{++}$

$\mathrm{Ca}^{++}$is essential for activation of the genetic information necessary for proliferation of lymphocytes in vitro. Chelatin of CaH with EGTA during the first 24 hours post PHA addition inhibited transformation. The molecular basis of $\mathrm{Ca}^{++}$regulation of proliferation is hypothetical, but it is likely that Ca+' activates calmodulin, which in turn activates enzymes stimulating cAMP, rRNA and DNA synthesis (Fig. 18). Circumstantial evidence supports the hypothesis that calmodulin may be the nucleolar protein which reacts with silver nitrate.

$$
\mathrm{Ca}+\mathrm{t} \text { is an important in vivo regulator of cell proliferation. }
$$
Lowering $\mathrm{Ca}^{++}$by removal of the parathyroid and low dietary intake, reversibly reduced cell proliferation in the bone marrow and thymus of rats (Whitfield et al., 1973). Most cellular responses to stimuli are mediated by $\mathrm{Ca}^{+}$fluxes. Cell proliferation is one of these. Cells from one culture group, treated with $1.8 \mathrm{mM}$ EGTA for the last 24 hours of 72 hour culturing period, had silver reactive spheres, which were dissociated from the nucleolus or NOR of metaphase chromosomes (Figs. $9 \& 10)$. The spheres were surrounded by a ring of satellite bodies composed of RNP-like material. This dissociation may be more than an artifact, even though the experimental conditions causing it were not defined.

$$
\text { Possibly intracellular } \mathrm{Ca}^{++} \text {was disturbed by EGTA, causing }
$$


chelation of nuclear $\mathrm{Ca}^{++}$and inactivation of nuclear calmodulin (Fig. 18). The inactivated calmodulin could then have dissociated from its active site, pulling RNP particles with it. This could implicate nuclear $\mathrm{Ca}+\mathrm{t}$ levels in the regulation of RNP transportation, in addition to regulation of rRNA synthesis.

Unusual metabolic patterns and behaviour of aberrant cells may be related to altered distributions of $\mathrm{Ca}+\mathrm{t}$ within the cells. CaH uptake of erythrocytes from cystic fibrosis patients was significantly reduced, due to decreased $\mathrm{Mg}^{++}$-and $\mathrm{Ca}^{++}$-ATPase activity (Ansah and Katz, 1980). Tumor cells invariably have low cytoplasmic $\mathrm{Ca}+$, and high levels in the mitochondria, indicating a lack of control of Cat+ cycling (Bygrave, 1978b). During transformation of a normal cell to a neoplastic cell there is often an increase in size and number of nucleoli (Busch and Smetana, 1970), which may be related to the altered Catt distribution. Control of rRNA synthesis is important in inhibition of tumor growth.

Because $\mathrm{Ca}+\mathrm{H}$ responds to and induces a wide range of events, understanding the regulation of the ionic environment is fundamental to understanding the functioning of normal and abnormal cells. 
REFERENCES

Alford, R.H. 1970. Metal cation requirements for phytohemagglutinininduced transformation of human peripheral blood lymphocytes. J. Immun. 104: 698-703.

Anghileri, L.J., and Heidbreder, M. 1978. Effects of extracellular $\mathrm{Ca}+t$ and $\mathrm{Mg}+t$ on nucleic acids and protein syntheses by tumor and normal liver cells. Int. J. Clin. Pharmacol. 16:451455 .

Ansah, T.-A., and Katz, S. 1980. Evidence for a Ca ${ }^{+H}$ transport deficiency in patients with cystic fibrosis. Cell Calcium 1: 195-203.

Arrighi, F.E.; Lav, Y.-F.; and Spallone A. 1980. Nucleolar activity in differentiated cells after stimulation. Cytogenet. Cell Genet. 26: 244-250.

Bernhard, W. 1966. Ultrastructural aspects of the normal and pathological nucleolus in mammalian cells. Nat. Cancer Inst. Monograph 23: 13-38.

Bernhard, W. 1971. Drug-induced changes in the interphase nucleus. Adv. in Cytopharm. 1: 49-67.

Bloom S.E., and Goodpasture G. 1976. An improved technique for selective silver staining of nucleolar organizer regions in human chromosomes. Human. Genet. 34: 199-206.

Brimacombe, R. 1976. Analysing the structure of the ribosome. TIBS 1(3): 181-183.

Brown, D.D., and Littna, E. 1964. RNA synthesis during the development of Xenopus laevis, the South African clawed toad. Mol. Biol. 8: $\overline{669-687}$.

Busch, H., and Smetana, K. 1970. The Nucleolus.pp. 626.Academic Press. N.Y.

Bygrave, F.L. 1978a. Calcium movements in cells. TIBS 3(8): 175-178.

Bygrave, F.L. 1978b. Mitochondria and the control of intracellular calcium. Biol. Reviews 53: 43-80. 
Cheung, W.Y. 1980. Calmodulin plays a pivotal role in cellular regulation. Science 207: 19-27.

Claret-Berthon, B.; Claret, M.; and Mazet, J.L. 1977. Fluxes and distribution of calcium in rat liver cells: kinetic analysis and identification of pools. J. Physiol. 272: 529-552.

Cocucci, S.M., and Sussman, M. 1970. RNA in cytoplasmic and nuclear fractions of cellular slime mold amebas. J. Cell Biol. 45: 399 .

Cooke, A., and Brown M. 1973. Stimulation of the activities of solubilized pig lymphocyte RNA polymerases by phytohoemagglutinin. Biochem. Biophys. Res. Comm. 51: 1042-1047.

Cooper, H.L. 1971. Biochemical alterations accompanying initiation of growth in resting cells. In: The Cell Cycle and Cancer. R. Baserga, ed. Marcel Dekker, Inc. N.Y. pp. 191-226.

Cooper, H.L. 1972. Studies on RNA metabolism during Iymphocyte activation. Transplant. Rev. 11: 3-38.

Cooper, H.L., and Gibson, E.M. 1971. Control of synthesis and wastage of ribosomal ribonucleic acid in lymphocytes. II The role of protein synthesis. J. Biol. Chem. 246: 5059-5066.

Crick, F.H.C. 1968. The Origin of the Genetic Code. J. Mol. Biol. $38: 367-379$.

Darne11, J.E. 1968. Ribonucleic acids from animal cells. Bact. Rev. 32: 262-290.

Dedman, J.R.; Potter, J.D.; Jackson, R.L.; Johnson, J.D. ; and Mean, A.R. 1977. Physiolochemical properties of rat testis Cattdependent regulator protein of Cyclic Nucleotide Phosphodiesterase. J. Biol. Chem. 252: 8415-8422.

Douglas, S.D. 1972. Electron microscopic and functional aspects of human lymphocyte response to mitogens. Transplant Rev. II: $39-59$.

Engel, W.; Zenzes, M.T.; and Schmid, M. 1977. Activation of mouse ribosomal RNA genes at the 2-cell stage. Hum. Genet. 38: $57-63$.

Estable, C., and Sotelo, J.R. 1951. Una nueva estructura celular: el nucleonema. Publ. Inst. Invest. Cien. Biol. 1: 105-126. 
Evans, H.J. 1977. Some facts and fancies relating to chromosome structure in man. Adv. Human Gen. 8: 347-438.

Gemsa, S.; Seitz, M.; Kramer, W.; Grimm, W.; Till, G; and Resch, K. 1979. Ionophore A 23187 raises cyclic AMP levels in macrophages by stimulating prostaglandin $\mathrm{E}$ formation. Expt1. Cell Res. 118: $55-62$.

Ghosh, S. 1976. The Nucleolar Structure. Int. Rev. of Cytol. 44: $1-28$.

Glasser, S.R., and Spelsberg, T.C. 1972. Mammalian RNA polymerases $I$ and II: Independent diurnal variations in activity. Biochem. Biophys. Res. Comm. 47: 951-958.

Goodpasture, C., and Bloom, S.E. 1975. Visualization of Nucleolar Organizer Regions in Mammalian Chromosomes Using Silver Staining. Chromosoma (Berl.) 53: 37-50.

Goodpasture, C.; Bloom, S.E.; Hsu; T.C.; and Arrighi, E. 1976. Human Nucleolus Organizers: The Satellites or the Stalks? Am. J. Hum. Genet. 28: 559-566.

Grasso, J.A.; and Woodard, J.W. 1966. The relationship between RNA synthesis and hemoglobin synthesis in amphibian erythropoiesis. J. Cell Biol. 31: 279.

Grouse, L.; Chilton, M.D.; and McCarthy, B.J. 1972. Hybridization of ribonucleic acid with unique sequences of mouse deoxyribonucleic acid. Biochemistry 11: 798-805.

Grant, W.D. 1972. The effect of $\alpha$-Amanitin and ( $\left.\mathrm{NH}_{4}\right)_{2} \mathrm{SO}_{4}$ on RNA Synthesis in nuclei and nucleoli isolated from physarum polycephalum at different times during the cell cycle. Eur. J. Biochem. 29: 94-98.

Grumm, I. 1978. In vitro synthesis of pre-rRNA in isolated nucleoli. The Cell Nucleus, Vol. V. Acad. Press. Ch. 11: 373-414.

Grummt, F.; Paul, D.; and Grummt, I. 1977. Regulation of ATP pools, rRNA and DNA Synthesis in 3 T3 cells in Response to Serum or Hypoxanthine. Eur. J. Biochem. 76: 7-12.

Hadjiolov, A.A. 1977. Patterns of ribosome biogenesis in eukaryotes. TIBS 2(2): $84-86$. 
Hadjiolov, A.A., and Nikolaev, N. 1976. Maturation of ribosomal ribonucleic acids and the biogenesis of ribosomes. Prog. Biophys. Molec. Biol. 31: 95-144.

Hamilton, L. and Kaplan, J.G. 1977. Flux of 86 Rb in activated human lymphocytes. Can. J. Biochem. 55: 774-778.

Hardin, J.H.; Spicer, S.S.; and Malanos, G.E. 1970. Quantitation of the ultrastructural components of nucleoli of rat trigeminal ganglia. J. Ultrastruct. Res. 32: 274-283.

Harper, J.F.; Cheung, W.Y.; Wallace, R.W.; Huange,H.-L.; Levine, S.N.; and Steiner, A.L. 1980. Localization of calmodulin in rat tissues. Proc. Nat1. Acad. Sci. 77: 366-370.

Hatlen, L., and Attardi, G. 1971. Proportion of Hela cell genome complimentary to transfer RNA and 5S RNA. J. Mo1. Biol.

56: $535-553$.

Heitz, E. 1931. Nukleolen und Chromosomes in der Gattung Vicia. Planta (Ber1.) 15: 494-505.

Henderson, A.S.; Warburton, D.; and Atwood, K.C. 1972. Location of Ribosomal DNA in the Human Chromosome Complement. Proc. Nat. Acad. Sci. (USA) 69: 3394-3398.

Hodge, L.D.; Robbins, E.; and Scharff, M.D., 1969. Persistence of messenger RNA through mitosis in HeLa Cells. J. Cell Biol. 40: 497-507.

Hofgärtner, F.J.; Krone, W.; and Jain, K. 1979. Correlated Inhibition of Ribosomal RNA Synthesis and Silver Staining by Actinomycin $D$. Hum. Genet. 47: 329-333.

Honjo, T., and Reeder, R.H. 1973. Preferential Transcription of Xenopus laevis Ribosomal RNA in interspecies Hybrids between Xenopus laevis and Xenopus mulleri. J. Mo1. Biol. 80: 217-228.

Hubbell, H.R.; Rothblum, L.I.; Hsu, T.C. 1979. Identification of a silver binding protein associated with the cytological silver staining of actively transcribing nucleolar regions. Cell. Biol. Int. Rep. 3: 615-622.

Jeanteur, P., and Attardi, G. 1969. Relationship between HeLa cell ribosomal RNA and its precursors studied by high resolution RNADNA hybridization. J. Mol. Biol. 45: 305-324. 
Karasaki, S. 1965. Electron microscopic examination of the sites of nuclear RNA synthesis during amphibian embryogenesis. J. Cel1 Biol. 26: 937-958.

Kay, J.E.; Leventhal, B.G.; and Cooper, H.L. 1969. Effects of inhibition of ribosomal RNA synthesis on the stimulation of lymphocytes by phytohemagglutinin. Exp. Cell Res. 54: 94-100.

Kornfield, R., and Kornfield, S. 1970. The structure of a phytohemagglutinin receptor site from human erythrocytes. J. Biol. Chem. 245: 2536.

Ledbetter, M., and Lubin, M. 1977. Control of protein synthesis in human fibroblasts by intracellular potassium. Exp. Cell Research 105: 223-236.

Lettre, R., and Siebs, W. 1954. Zur Stuktur des Nucleolus. Naturwissenschaften $41: 458$.

Lettre, R.; Siebs, W.; and Paweletz, N. 1966. Morphological observations on the nucleolus of cells in tissue culture, with special regard to its composition. Natn. Cancer Inst. Monogr. 23: 107-123.

Lezzi, M. 1970. Differential Gene Activation in Isolated Chromosomes. Int. Rev. of Cytology 29: 127-168.

Ling, N.R. 1968. Lymphocyte Stimulation. North Holland Publ. Co. Amsterdam.

Liu, Y.P., and Cheung, W.Y. 1976. Cyclic 3: 5- Nucleotide Phosphodiesterase. J. Biol. Chem. 251: 4193-4198.

Lubin, M., and Ennis, H.L. 1964. On the role of intracellular potassium in protein synthesis. Biochim. Biophys. Acta. 80: 614-631.

Markovic, V.D.; Worton, R.G.; and Berg, J.M. 1978. Evidence for the Inheritance of Silver-Stained Nucleolus Organizer Regions. Human Genet. 41: 181-187.

Means, A.R., and Dedman, J.R. 1980. Calmodulin in endocrine cells and its multiple roles in hormone action. Molecular and Cell. Endocrinology 19: 215-227.

Mikelsaar, A.-V.; Schwarzacher, H.G.; Schnedl, W.; and Wagenbichler, P. 1977. Inheritance of Ag-Stainability of Nucleolus Organizer Regions. Human. Genet. 38: 183-188.

Miller, D.A.; Dev, V.G.; Tantravahi, R.; and Miller, O.J. 1976a. Suppression of human nucleolus organizer activity in mousehuman somatic hybrid cells. Expl. Cell Res. 101: 235-243. 
Miller, O.J.; Miller, D.A.; Dev, V.G.; Tantravahi, R.; and Croce M. 1976b. Expression of human and suppression of mouse nucleolus organizer activity in mouse-human somatic cell hybrids. Proc. Natl. Acad. Sci. (USA) 73(12): 4531-4535.

Miller, O.L., Jr., and Hamkalo, B.A. 1972. Visualization of RNA synthesis on chromosomes. Int. Rev. Cytol. 33: 1-25.

Morimoto, K., and Wolff, S. 1980. Cell Cycle Kinetics in Human Lymphocyte Cultures. Nature 288: 604-606.

Negendank, W., and Shaller, C. 1979. Potassium-Sodium Distribution in Human Lymphocytes: Description by the AssociationInduction Hypothesis. J. Cell Physiol. 98: 95-106.

Nowe11, P.C. 1960. Phytohemagglutinin: An Initiator of Mitosis in Cultures of Normal Human Leukocytes. Cancer Res. 20: $462-466$.

Ohno, S.; Trujillo, J.M.; Kaplan, W.D.; Kinosita, R.; and Stenius, C. 1961. Nucleolus organizers in the causation of chromosomal anomalies in man. Lancet 1961 II: 128-136.

Olert, J.; Sawatzki, G.; Kling H.; and Gebauer, J. 1979. Cytological and histochemical studies on the mechanism of the selective silver staining of nucleolus organizer regions. Histochemistry 60: 91-99.

Owens, Ov. H.; Gey, M.K.; and Gey, G.O. 1958. The effect of calcium and magnessium on the growth and morphology of mouse lymphoblasts in tissue culture. Cancer Res. 18: 968-973.

Perris, A.D.; Whitfield, J.F.; and Rixon, R.H. 1967. Stimulation of mitosis in bone marrow and thymus of normal and irradiated rats by divalent cations and parathyroid extract. Radiat. Res. 32: 550-563.

Pollack, M., and Fisher, H.W. 1976. Dissociation of ribonucleic acid and protein synthesis in mammalian cells deprived of potassium. Archives of Biochem. \& Biophy. 172: 188-190.

Purtell, M.J., and Anthony, D.D. 1975. Changes in ribosomal RNA processing paths in resting and phytohemagglutinin stimulated guinea pig lymphocytes. Proc. Nat. Acad. Sci. 72: 3315-3319.

Quastel, M.R., and Kaplan, J.G. 1970a. Lymphocyte stimulation: The effect of olabain on nucleic acid and protein synthesis. Exp. Cell Res. 62: 407-420. 
Quaste1, M.R., and Kaplan, J.G. 1970b. Early stimulation of potassium uptake in lymphocytes treated with PHA. Exp. Cell Res. 63: 230-233.

Rasmussen, H. 1970. Cell communication, calcium ion and cyclic adenosine monophosphate. Science 170: 404-413.

Ray, M., and Pearson, J. 1979. Nucleolar Organizing Regions of Human Chromosomes. Hum. Gen. 48: 201-210.

Recher, L.; Briggs, L.; and Parry, N.T. 1971. A reevaluation of nuclear and nucleolar changes induced in vitro by Actinomycin D. Cancer Res. 31: 140-151.

Ringertz, N.R.; Carlsson, S.-A.; Ege, T.; and Bolund, L. 1971. Detection of human and chick nuclear antigens in nuclei of chick erythrocytes during reactivation in heterokaryons with Hela cells. Proc. Nat. Acad. Sci. 68: 3228.

Roeder, R.G.; Reeder, R.H.; and Brown D.D. 1970. Multiple forms of RNA polymerase in Xenopus laevis: Their relationship to RNA synthesis in vivo and their fidelity of transcription in vitro. Cold Spring Harbour Symp. Quant. Biol. 35: 727-735.

Rosenstreich, D.L., and Blumenthal, R. 1977. Ionophorous activity and murine B lymphocyte mitogens. J. Immunol. 118: 129-136.

Rubin, A.D. 1971. Defective control of ribosomal RNA processing in stimulated leukemic 1ymphocytes. J. Clin. Invest. 50: $2485-2497$.

Rudland, P.S.; Weil, S.; and Hunter; A.R. 1975. Changes in RNA metabolism and accumulation of presumptive messenger RNA during transition from growing to the quiescent state of cultured mouse fibroblasts. J. Molec. Biol. 96: 745-766.

Ruzicka, W. 1891. Zur Geschichte und Kenntnis der feineren Structur der Nucleolen centraler Nerzellen. Anat. $A_{n}$. 16: $557-563$.

Schwarzacher, H.G.; Mikelsaar, A-V.; and Schned1, W. 1978. The nature of the Ag-staining of nucleolus organizer regions. Cytogenet. Cell Genet. 20: 24-39.

Sidebottom, E., and Harris, H. 1969. The role of the nucleolus in the transfer of RNA from nucleus to cytoplasm. J. Cell Sci. 5: $351-364$. 
Smith, J.W.; Steiner, A.L.; Newberry, W.M.; and Parker, C.W. 1971. Cyclic adenosine 3, 5- monophosphate in human lymphocytes. Alterations after phytohemagglutinin stimulation. J. Clin. Invest. 50: $432-441$.

Spring, H.; Trendelenburg, M.F.; Scheer, U.; Franke, W.W.; and Herth, W. 1974. Structural and biochemical studies of the primary nucleus of two green algae species, Acetabularia mediterranea and Acetabularia major. Cytobiologie 10: 1-65.

Sulakhe, P.V., and St. Louis, P.J. 1980. Passive and active calcium fluxes across plasma membranes. Prog. Biophys. Molec. Biol. 35: $135-195$.

Tres, L.L. 1975. Nucleolar RNA synthesis of meiotic prophase spermatocytes in the human testis. Chromosoma (Berl.) 53: 141-151.

Whitfield, J.F.; Boynton, A.L.; MacManus, J.P.; Rixon, R.H.; Sikorska, M.; Tsang, B.; and Walker, P.R. 1980. The roles of calcium and cyclic AMP in cell proliferation. Ann. N.Y. Acad. Sci. 339: 216-240.

Whitfield, J.F.; Boynton, A.L.; MacManus, J.P.; Sikorska, M.; and Tsang, B.K. 1979. The regulation of cell proliferation by calcium and cyclic AMP. Molecular and Cellular Biochem: 27: $155-179$.

Whitfield, J.F.; MacManus, J.P.; Braceland, B.M.; and Gillian, D.J. 1972. The influence of calcium on the cyclic AMPmediated stimulation of DNA synthesis and al1 proliferation by prostaglandin $E_{\mathbb{g}}$. J. Cell Physiol. 79: 353-362.

Whitfield, J.F.; Perris, A.D.; and Rixon, R.H. 1969a. Stimulation of mitotic activity and initiation of deoxyribonucleic acid synthesis in populations of rat thymic lymphocytes by magnesium. J. Cell. Physiol. 74: 1-8.

Whitfield, J.F.; Rixon, R.H.; and Perris, A.D. 1969b. Stimulation by calcium of the entry of thymic lymphocytes into deoxyribonucleic acid-synthetic(S) phase of the cell cycle. Exp. Cell Res. $57: 8-12$.

Whitfield, J.F; Rixon, R.H.; MacManus, J.P.; and Balk, S.D. 1973. Calcium, cyclic adenosine 3, 5'- Monophosphate, and the control of cell proliferation: A Review. In Vitro 8: 257-278. 
Whitney, R. 1972. Enhanced uptake of calcium by transforming 1ymphocytes. Cel1. Immun. 5: 137-147.

Whitney, R.B., and Sutherland, R.M. 1972. Requirement for calcium ions in lymphocyte transformation stimulated by Phytohemagglutinin. J. Cell Physiol. 80: 329-338.

Yang, D.-P., and Morton, H.J. 1971. Effect of Calcium and Magnesium on the Morphology and Growth Pattern of L-M Cells. J. of Natl. Canc. Inst. 46: 505-515. 